\title{
Yaratıcı Drama ile Dans Devinim Becerisi ve Beden Farkındalığının Geliştirilmesi
}

\author{
Bahar Gürey ${ }^{1}$
}

Ömer Adıgüzel ${ }^{2}$

\begin{abstract}
$\ddot{O} z e t$
Çalışmada, yaratıcı drama yöntemi ile yaratıcı drama ĕgitmen adaylarının beden farkındalı̆̆ becerileri ile bedenle ifade becerilerinin geliştirilmesi amaçlanmıştır. Çă̆daş Drama Derneği (ÇDD) İstanbul Şubesi'nde yaratıcı drama eğitmenliği programına katılan 3 ve üst aşamalardan oluşan 3 'ü erkek 10'u kadın, toplam 13 kişinin gönüllü katılımı ile gerçekleştirilen çalışmanın uygulamaları, 06.04.2012 - 28.04.2012 tarihleri arasında toplam 24 saat içerisinde gerçekleştirilmiştir. Yaratıcı drama yöntem ve tekniklerinden yararlanarak sözsüz anlatımların yoğun olarak ortaya konduğu çalışmada nitel araştırma desenlerinden durum çalışması deseni kullanılmıştır. Araştırma kapsamında veri toplama aracı olarak öntest sontest, katılımcı tanıma formu, katılımcı ürünleri (resimler, şekiller, şiirler), kişisel dans tarihleri ve gözlem ödevleri, katılımlı gözlemci olarak liderin atölyeler hakkındaki düşünceleri, video gözlem kayıtları gibi farklı veriler kullanılarak veri çeşitliliği sağlanmıştır. Ulaşılan verilerin analizinde betimsel analiz kullanılarak araştırma bulguları katılımcı görüşlerinden yapılan doğrudan alıntılarla desteklenmiştir. Uygulama sonrasında yapılan değerlendirmeler, katılımcıların; müzik ve söz olmadan devinebildiklerini, beden farkındalı̆̆ ile doğaçlama ve rol oynama esnasında bedenlerini daha kontrollü kullanabildiklerini, devinim becerilerinin gelişmesi ile sözsüz doğaçlama yapabildiklerini ve dans becerilerinin gelişmesi ile devinimlerini estetik kılabildiklerini göstermektedir.
\end{abstract}

Anahtar kelimeler: Dans, devinim, yaratıcı drama, yaratıcı dans, beden farkındalığl, ifade dili olarak beden

\section{Developing dance Body Movement Skills and Body Awareness With Creative Drama}

\begin{abstract}
Project was realized with the participants who completed 3rd,4th and 5th stage in Contemporary Drama Association Creative Drama Educator/Leadership program. To develop body awareness and dance, movement skills, the development of expression skills of leader candidates as an educator using their body, by transferring these experiences to improvisation and role playing is aimed for. The project was made with the participants who attended Contemporary Drama Association Creative Drama Educator/Leadership program. The project participants were 13 people (3 male-10 female). Applications of the study was carried out in between 06.04.2012 - 28.04.2012 total within 24 hours. In this research qualitative data is collected by case study. Pre test-final test, personal dance histories of the participants, video observation records were used for the data collection varieties. After the collection of datas descriptive analyse used for the research findings and it is supported with participant views-sentences. By using the creative drama method and techniques, role playing and improvisation were mostly made with nonverbal expressions were put forward. In the evaluations
\end{abstract}

1 Çă̆daş Drama Derneği Eğitmeni, bagurey@hotmail.com

2 Doç. Dr. Ankara Üniversitesi Eğitim Bilimleri Fakültesi Öğretim Üyesi, omeradiguzel@gmail.com 
after the implementation, it is seen that the participants could move without music and words, they could use their bodies in a more controlled manner with body awareness and during improvisation and role playing that they were able to improvise without words with the development of movement skills and they were able to make their movements aesthetical with the development of dancing skills.

Key words: Dance, movement, creative drama, creative dance, body awareness, body as an expression language

\section{Giriş}

Yaratıcı dramanın hazırlık/1sınma ve canlandırma aşamalarında; beden sıklıkla odakta olur. Bu süreçlerde birey bir tür enstrüman olan bedenini ne kadar iyi tanırsa, bedenine o kadar hakim olur. Bunun sonucunda birey kendini bedeni aracılığı ile ifade ederken, bedenini bir iletişim aracı olarak da kullanır.

Kişi, dil düzeyinde bir şey ifade ederken -sözgelimi bir şeyleri gizlemek isterken- bedeni tam tersi bir ifadede bulunabilir ve bu form kişinin düşüncesini doğrudan yansıtabilir. Bu açıdan bakıldığında, sanılanın tersine iletişimde etkili organın dil değil beden olduğu ortaya çıkar. Sözsüz iletişim olarak adlandırılan beden dilinde kişinin duruşu, mimik ve jestleri, gestusu (kişinin sınıfsal konumunu belli eden bedensel tavır) o kişinin düşünce dünyasını ele veren ögeler arasında yer alır.

Bir grup çalışması olan yaratıcı drama çalışmalarında tıpkı gündelik yaşantılarında olduğu gibi katılımcılar hem sözlü hem de sözsüz iletişim kurarlar. Canlandırmalar sırasında kendiliğinden gelişen sözel ve bedensel diyaloglar, katılımcıların içinde bulundukları rolde doğaçlamanın başlangıcını, gelişimini ve sonucunu belirler. Ancak bu süreçte katılımcılar bedenleriyle kurdukları iletişimi geri planda bırakarak daha çok konuşmaya -sözel iletişime- yönelebilmektedirler. Doğaçlamalarda çoğunlukla sözel iletişime ağırlık verilmesi ve sözsüz iletişimin kullanılmaması yer yer durağanlığa neden olabilmekte ve yalnızca tümcelerin kurulduğu bir doğaçlama ortaya çıkabilmektedir.

Adıgüzel (2010)'e göre yaratıcı drama eylem gerektirir. Eylem dilden daha öndedir ve hareket de eylemin içinde var olur. Bu nedenle doğaçlamalarda daha çok harekete ağırlık vermek doğaçlamaları da zenginleştirebilir. Duygu ve düşüncelerin bedenle aktarımı sırasında devinirken beden de kullanıldığından hareket içinde düşünme ve ifade etme olanağı ortaya çıkar. Böylece yaratıcı drama eğitiminde eğitmen adaylarının sözlü ve sözsüz iletişimlerinde bedenlerinin akıcılık kazanmasına, hareket ve motivasyonlarının artmasına yönelik çalışmalar yapılması önem kazanır.

\section{Bedenin Tarihsel Süreci}

Beden, TDK sözlüğünde "Canlı varlıkların maddi bölümü, vücut.” olarak tanımlanır. Tarihsel antropolojiye göre beden, ifade ve temsilin aracı olarak ele alınır. Buttler bedeni; kendini maddileştiren yani bedenin geçerliliği için didinen, öznenin bedeni ve toplumsal cinsiyeti temsil eden beden olarak üçe ayırır (Buttler'dan akt.Wulf, 2009). Bedenin tarihsel sürecine bakıldığında antik dönemde bedenin değerli olduğu görülür. Tanrılar ve tanrıçalar kusursuzdur. Zeus, şimşek ile gök gürültülerinin ve dünyanın hâkimidir. Herkül'ün 12 görevi onun korkusuz ve fiziksel olarak ne kadar güçlü olduğunu ortaya koyar. Denizin köpüklü dalgalarından doğduğu söylenen Afrodit güzelliğin sembolüdür (Can, 1997). Ortaçağ'da ise beden değerini kaybeder ve günahkâr olarak görülür. Bedensel zevkler, katı kurallarla kısıtlanmıştır. Keşişler için pis beden erdem sayılmıştır (Yaşayan, 2009). Kadınlar cadılıkla suçlanmış ve bedenleri yakılarak cezalandırılmıştır. Rahipler çile odalarında bedenlerini kırbaçlayarak, demir zincirlerle döverek cezalandırmışlardır; zira beden günahkârdır ve şeytanla işbirliği içindedir. Rahipler ve rahibeler evlenmez. Cinsellik dünyevi zevklerdendir. Cinsellik yalnızca çocuk doğurmak için bir araçtır. 
Leonardo da Vinci, Michelangelo, Boticelli gibi Rönesans sanatçıları ile birlikte beden yeniden değer kazanır ve güzel olarak betimlenir. Böylece beden kötü, günahkâr ve düşman olmaktan kurtulmuş, ruhun içinde bulunduğu kap olmaktan da çıkmış olur (Yaşayan, 2009). Birinci Dünya Savaşı'nı da kapsayan çağdaş dönemde ise beden, iktidar tarafından kontrol altında tutulan, yönetilen, yönlendirilen bir nesne konumundadır. Disipline edilmiş olan beden, daha da ileri dönemlerde özgürleşip özel mülk haline gelmiş ve her birey kendi bedeninden sorumlu olmuştur. 1960'lı yıllardaki cinsel devrim ile birlikte mevcut ahlak anlayışı da değişmiş, sınıf ayrımına karşı çıkılmış, öteki olma durumu reddedilmiş, rengi, bulunduğu sınıf ve cinsel tercihleri nedeniyle dışlanan kişiler kendilerini daha rahat ifade etme özgürlüğünü elde etmeye başlamışlardır.

\section{Bedenin Ĕgitimdeki Yeri}

Eğitim sürecinde beden, öğrenmenin bir parçası haline gelmiştir. Öğrenme sırasında etkin olan çocuk, yaparak ve uygulayarak daha iyi öğrenmekte ve öğrenme kalıcı olmaktadır. Gardner'e göre her birey, sahip olduğu zekâlarla farklı öğrenme, sorun çözme becerisine ve yetisine sahiptir (Gardner, 2004). Her bireyin, bireysel farklılıklarına göre sahip olduğu bazı zekâ türleri daha baskınken bazıları çekiniktir. Bireylerin sahip oldukları zekâ türleri, bireysel özelliklerinin farklı olması nedeniyle farklı gelişim sürecine sahiptir. Bu zekâ türlerinden biri de kinestetik zekâ olarak adlandırılan bedensel zekâya karşılık gelmektedir. Bedensel zekânın özellikleri arasında duygu ve düşüncenin, bedenin bir bölümü ya da tamamıla ifade edilmesi yer almaktadır. Kişi, bedensel tepkilerini kontrol edebilir; farkındalığını bedene aktarabilir; zihin ve beden bağlantısı kurabilir; taklit becerisine; geliştirilmiş bedensel işlevlere sahip olabilir.

Bedenin önemsenip öğrenmede aktif hale gelmesi düşüncesiyle birlikte, 20.yy. başında H.F. Johnson ve CaldwellCook, 20. yy. ortasında Peter Slade ve 20. yüzyılın 2. yarısında Brain Way, Dorothy Heathcote, Gavin Bolton gibi eğitimciler, "yaparak ve uygulayarak öğrenmenin” öğrenciyi pasif dinleyen durumundan çıkarıp gönüllü katılımcı durumuna getireceği yaratıcı drama çalışmalarını gerçekleştirmişlerdir. Burada başlangıçtan günümüze doğru doğaçlamanın, rol oynamanın artarak önem kazandığı görülmektedir. Heathcote'a göre, drama yaşamın provasıdır. Hans-Wolfgang Nickel, belirsizlik durumlarının bir yönüyle doğaçlamanın başlangıçlarını oluşturduğunu dile getirir. Gündelik yaşantımızda bir durumla karşılaştığımızda bunu yaşamaya başlarız ve ne dediğimizi ne yaptığımızı sonradan değerlendiririz (Adıgüzel, 2010).

\section{Sanatsal Bir Form Olarak Dans}

Kinestetik zekâ kapsamında tanımlanan bedensel ifadeler, ritüellerle başlayan süreçle birlikte bedenin ilerleyen dönemlerde sanat malzemesi olmasını sağlamıştır. Tiyatro, dans, sirk gibi sanatsal alanlarda beden ön plana çıkmış ve bedenin eylemlerinin sanata dönüştüğü görülmüştür. Dans, bir anlamda insan psikolojisinin beden içindeki hapsoluşundan kurtulup bedenine dışarıdan bakabilmesi ve aynı zamanda dışarıdaki bedenselliği fark etme süreci olarak betimlenebilir. Dans, aynı zamanda bireyin sözel olmayan bir ifade aracı, bedeni aracılığılyla gerçekleştirdiği gündelik hareketleri fark edip, bu hareketleri geliştirerek duygu ve düşüncelerini sanatsal bir form içinde yeniden keşfettiği önemli bir olgudur.

Paulson'a göre dans "Hissetmek, anlamak ve iletişim kurmak için hareketin araç olduğu bir sanat dalıdır.”(Akt. Özevin ve Bilen, 2011). Bu tanımdan yola çıkarak dansın metaforik bir dil olduğundan söz edilebilir. Bu dil bedenle ifade edilir. Beden nasıl bir toplumun ayrılmaz bir parçası olup toplumun gelişimi ve değişimi ile paralellik gösteriyor ve farklı anlamlar taşıyorsa, dans da bedenle gerçekleştirilen bir sanat formu olarak canlı, yaşayan ve toplumla birlikte değişim ve gelişim gösteren sözel olmayan bir iletişim aracıdır. Curt Sachs, "Her yüksek kültür geçmişinden gelen ruhsal bir mirasa sahiptir, bütün dünyevilerin ve insanüstülerin hareketlerindeki yüce kavram danstır.” görüşündedir (Akt. Özevin ve Bilen, 2011). Bu çalışmada sözü edilen 
yaklaşımlarla dans süreçsel bir bakış açısıyla kişinin kendini tanıması, yaratıcılığını ve hayal gücünü tetiklemesi ve duygularını aktarmasında öznel olarak ele alınmıştır.

\section{Dansın Ögeleri}

Dansın temel ögeleri olan mekân, zaman ve insan bedeni, bu çalışmanın da temel taşlarını oluşturmaktadır. Bu kapsamda amaç, katılımcıların profesyonel dansçılar olmaları değil, kendilerini ve bedenlerini tanımaları, etkili biçimde kullanmaları, sosyal iletişim kurmaları ve yaratıcılıklarını ortaya koymalarıdır. Bu nedenle Özevin ve Bilen'in Yaratıcı Dans (2011) kitabında yer alan Preston- Dunlop'un (1992) mekân, zaman, beden, hareket kalitesi ve ilişki başlıklarından oluşan dansın ögelerinden doğrudan yararlanılmıştır.

"Dansı oluşturan temel ögeler mekân, zaman ve insan bedenidir. Dansta partner olarak genellikle ritmik vuruşlar ve müzikten yararlanılsa da, dans bağımsız bir sanattır ve işitsel eşlik olmaksızın da var olabilir. Dans aynı zamanda, mimarlık ve plastik sanatlar gibi mekân içinde bir düzendir ve mekânsal ritimden yararlanır. Müzikte olduğu gibi zaman içinde bir düzenlemedir ve zaman ritminden yararlanır. Dolayısıyla dans, hem görsel hem işitsel ritmi kullanan, bir zaman-mekân sanatıdır" (Pavis’ten akt; Coşkun, 2008).

\section{Dans ve Oyun İlişkisi}

İlk insanların akşam ateş başında sergiledikleri avlanma süreci ve benzeri taklitlerin ritüellere açıldığı, fakat her ikisinin kaynağında da oyun olduğu söylenebilir; çünkü bazı bilim insanları oyunun kökenini ve temelini yaşam sevinci fazlalığının belirlediği bir olgu olarak görmüş, kimi bilim insanlarıysa canlı varlıkların oyun oynama ihtiyacının doğuştan gelen bir taklit yeteneğinin hükmü altında olduğunu, oyun yoluyla yaşamın ondan talep edeceği ciddi etkinliklere hazırlık yaptığını dile getirmiştir (Huizinga, 2010). Avlanma sürecinin canlandırılması, yarınki ava hazırlık olabileceği gibi bir yandan da oynayan ve seyreden kişiler için bir haz alma sürecidir. Oyun; taklit, dans ve ritüelle dolayısıyla kültürle birebir ilişki içindedir.

Toplumlar, bedensel devinim ile kendi kültürlerini ifade ederler. Her kültürün kendine özgü yapısı, yaşayış biçimi ve ifade özgünlüğü vardır. İnsanlar kendilerine ayna tutuluyormuşçasına bu sayede kendilerini yeniden tanırlar. Oyunların hemen hepsinde devinim söz konusudur. Bu bağlamda devinim, oyun kavramının önemli bir ögesidir.Winnicot'a (1998) göre varoluşun tümü oyun oynama üzerine kuruludur. Kişi, oyun oynama esnasında içedönük ya da dışadönük olma durumunda değildir. Şimdi ve burada olarak anı yaşar. Nesnel ve öznel gözlemin kesiştiği noktada durur. İnsan ister çocuk ister yetişkin olsun, ancak oynarken yaratıcılığını ve tüm kişiliğini ortaya koyabilir ve ancak yaratıcı olduğunda kendini keşfedebilir. Dans ederken de kişi, şimdi ve burada olma anını yaşar. Kendini olduğu gibi yansıtarak kişiliğini ortaya koyar. Aynı zamanda kendini keşfetme sürecindedir. Oyun oynarken de dans ederken de kişi,her iki eylemi istediği sürece devam ettirir. Oynadıkça ve dans ettikçe açığa çıkan enerji, fazla enerji kuramına göre fişkıran enerjidir ve giderek artar. Kişi dans etmeye de oynamaya da devam eder. Hem oyunda hem de dansta devinim ifade aracidır.

\section{Dans ve Ritüel İlişkisi}

Ritüellerin, ilkel insanın doğayla ve tanımlayamadığı güçlerle ilişki kurabilmek için üretildiği ve tiyatro sanatının da kökenini oluşturduğu kabul edilir (Çalışlar'dan akt; Coşkun, 2008). Tiyatronun doğa olayları ve tanımlayamadıkları güçlere hâkim olmak için yapılan dinsel- büyüsel törenlerdeki taklitten ortaya çıktığına inanılmaktadır. İlkel törenlerdeki taklit araçları arasında maske ve dans sayılabilir. Öldürülen hayvanın kafasını kendi başına takmak maskenin; avı kutlama amaçlı ortaya çıkan devinim ise, dansın gelişimine katkı sunmuş olabilir. Doğaya karşı direnen ilk (ilkel) insanlar, ritüel aracılığı ile kendi güçlerini arttırma çabasına girmiş ve bu durum onların aynı zamanda içinde bulundukları topluluk ile bağlarını kuvvetlendirip dayanışma duygusunu 
geliştirmiştir. $\mathrm{Bu}$ sebeple ritüelin simgesel bir eylem olduğu, içinde bulunduğu toplumun ögelerini taşıdı̆̆ söylenebilir. Toplumun ögeleri ile söz edilen; o topluma ait davranışlar, gelenekler, adetler, törelerdir. Bedene yansıyan devinimler, o topluma ait ögeleri yansıtır. Böylece ritüel esnasında ortaya çıkan ve dansa dönüşen devinimler, o toplumun kendini yeniden tanıması ve anlaması için olanak verir. Bu yansıtma; kültür, toplum, beden ve dans arasında doğrudan bir ilişki olduğunu gösterir.

\section{Yaratıcı Drama ve Dans İlişkisi}

Müzik, dans, edebiyat, resim, tiyatro ve sinema gibi sanat dalları arasından biri ya da birkaçıla birden ilgilenen kişi, kendini - duygu ve düşüncelerini- aktarma ve aynı zamanda kendini tanıma sürecindedir. Kişi, sanat aracılığı ile kendini ifade edecek işler ortaya koyarken bunların yalnızca sözlü anlatımlar olmadığı görülür; çünkü deneyimlerin, çağrışımların ve duyguların yalnızca sözlü anlatımla ifadesi söz konusu değildir. Hareket içeren sanat dallarında kişi, içinde bulunduğu duygu durumunu olabildiğince özgür bir şekilde ifade edebilir. Sayısız cümle yerine gösterilen bir hareket, bazen çok daha etkili bir anlatım sağlayabilir. Pina Bausch, "Bazı durumlarda kişinin o duruma dair söyleyecek sözü olmadığında yapılması gereken hissettirmektir." derken, sözcüklerin bir şeyleri harekete geçirmekte yetersiz kaldığını, dansın da tam bu noktada ortaya çıktığını dile getirir. Dille ifade edilemeyen, dansta ortaya çıkabilir (Wenders, 2011).

Dansta bir ifade biçimi olarak beden kullanılır. Bedenin yaratılan yeni evrende daha doğrusu dans edilen mekânda estetik biçimde kullanılması söz konusudur. Bu esnada kişi ya kendi bedeniyle ya başkasının bedeniyle ya da bir nesne ile ilişkilenir. Bu ilişkilenme biçimlerinin bedende ortaya koyduğu hareket, kişinin iç dünyasından başlayabileceği gibi dış dünyasından da başlayabilir. Kişi duygu ve düşüncelerini, ihtiyaçlarını ifade edebileceği gibi, diş dünyadan edindiği izlenimleri de aktarabilir. Bununla ilgili olarak Haselbach (1981) devinim esnasındaki akışı, dış dünyadan iç dünyaya ya da tam tersi bir yönde belirtmiştir.

A. Doğaçlama Sırasında Dış Dünyadan İç Dünyaya Doğru Yönelen Akış

- Dış Dünyadan İzlenimler ( insan ilişkileri, çevre, doğa, sanat... vb. gibi)

- Algilama

- Deneyim-bilinç oluşturma

- $\quad$ İç dünya

B. Doğaçlama Sırasında İç Dünyadan Dış Dünyaya Doğru Yönelen Akış

- İç Dünya (Duygular düşünceler, ihtiyaçlar vb. gibi)

- İfade ihtiyac1

- Formlar yaratma isteği

- Dış Dünyanın yeni ve etkileyici ürünü olarak form ve içerikle anlık kompozisyonlar (Akt; Özevin ve Bilen, 2011).

$\mathrm{Bu}$ ifade etme sürecinde kişi, bedenini bir iletme aracı olarak kullanır. Bedenini serbestçe hareket ettirerek devinir. Bu devinim süreci, kişinin kendini içinden geldiği gibi (otantik) hareket ettirmesi, kendiliğinden devinmesi bir başka ifade ile hareketlerini doğaçlamasıdır. Bu esnada kişi kendini tanıma ve keşfetme sürecindedir. Yapabildiklerini ve sınırlarını, dans ederken açığa çıkan enerjisini fark eder. Bir grup ile dans ediyorsa bir bütünün parçası olur ve grubun enerjisi ile hareket eder. İçinde bulunduğu uzamla bedenselliği aracıllğıyla iletişim kurar. 
Doğaçlamanın başlaması için kişiye birtakım uyaranlar ve güdüleyiciler verilebilir. Minton (1997)'a göre bunlar görsel, işitsel, dokunsal, kinestetik uyaranlar ve sahne malzemeleri ile hayaller ve tasvirlerdir (Minton'dan akt; Özevin ve Bilen, 2011). Çalışmada katılımcılara verilen uyaranlar ve güdüleyicilerle elde edilen materyaller, katılımcılara tekrar doğaçlamada kullanılmak üzere verilmiştir. Böylelikle doğurgan bir yap1 kullanılarak katılımcıların devamlı üretmeleri sağlanmıştır.

Yaratıcı dramanın odağında yer alan doğaçlama ve rol oynama teknikleri, içinde eylem ve hareket barındırır. Bir grup etkinliği olan yaratıcı drama çalışmalarında doğaçlama hazırlayan grup, bu esnada yaratıcı dramanın -en çok bu aşamada- kazanımlarına (demokratik tutum davranış geliştirme, estetik bakış açısı geliştirme, bir bütünün parçası olma, birlikte hareket etme, yaratıcılığı ortaya çıkarma, duygudaşlık kurma vb.) erişme olanağı yakalar. Doğaçlama hazırlayan kişi, eylem içinde, kendini tanıma, yaratıcılığını geliştirme, birlikte hareket etme, grup içinde iletişim- etkileşim kurma sürecine girer. Bu süreç aynı zamanda oyun oynarken de varlığını sürdürür.

Yaratıcı drama eğitimi alan katılımcı, bedenini kullanmakta kısıtlama yaşıor ve doğaçlama yalnızca sözel ifade ile sınırlı kalıyorsa anlatımda kısır döngüler oluşabilir. Bu bağlamda gerçekleştirilecek devinim, dans ve beden farkındalığı çalışmaları, katılımcıların doğaçlama esnasında 1raksak ifadeleri kullanmaları açısından katk1 sağlayabilir.

Yukarıda sözedilen yaratıcı drama ve dans disiplinlerinde yer alan kendini tanıma, yaratıcılık, birlikte hareket etme, iletişim-etkileşim, eylem gibi ortak kavramlar göz önünde bulundurulduğunda, yapılan bu disiplinlerarası çalışma ile kişilerin kendilerini beden farkındalığı ve devinim konusunda geliştirmeleri hedeflenmiştir. Kişi, devinim esnasında endorfin salgıladığı için kendini daha iyi ve zinde hisseder. Performans kaygısı güdülmediği ve söze dayalı doğaçlama yapılmadığı için süreçte özgüven içinde hareket eder ve etkinliklerde kendi otantik hareketini arar. Bu ifade biçimi kişinin gündelik yaşantısına olumlu yansır. Böylece kendine güvenen, kendini rahatça ifade eden, algısı açık bir birey haline gelebilir. Özgür bedene sahip birey, sahip olduğu özgür bakış açısıyla içinde yaşadığı topluma yaklaşabilir; onu değiştirmeye ve dönüştürmeye başlayabilir.

\section{Çalışmanın Amacı}

Çalışmada, yaratıcı drama eğitmen adaylarının yaratıcı drama yöntemi ile beden farkındalığının, dans, devinim becerilerinin ve beden ile ifade becerilerinin geliştirilmesi amaçlanmıştır.

\section{Yöntem}

Bu çalışmada nitel araştırma desenlerinden “durum çalışması (Case study)” deseni kullanılmıştır. Durum çalışmaları; bir program, bir kişi, bir işlem, bir süreç, bir kurum ya da bir sosyal grup gibi spesifik bir olguyu derinlemesine araştırmak için oldukça elverişli bir desendir. Durum çalışmaları, bir olguyu ayrıntılı biçimde inceler ve uygulamaya olanak verir (Merriam, 2009 akt. Türker, B., 2011).

Araştırmada veri toplama aracı olarak uygulama öncesi ve sonrasında öntest ve sontest olarak kullanılmak üzere 10 soru hazırlanmıştır. Uygulama başlamadan önce sorulan sorular, uygulamanın bittiği son oturumda tekrar sorulmuştur ve soruların yanıtları arasınndaki farklılıklar incelenmiştir. Soruların yanıtlanmasında derecelendirme kullanılmadan, katılımcıların kendi cümlelerini kurmaları önemsenmiştir. Yapılan çalışmada; katılımcı tanıma formu, katılımcı ürünleri (resimler, şekiller, şiirler), kişisel dans tarihleri ve gözlem ödevleri, katılımlı gözlemci olarak liderin atölyeler hakkındaki düşünceleri, video gözlem kayıtları gibi farklı veriler kullanılarak veri çeşitliliği sağlanmıştır. Ulaşılan verilerin analizinde betimsel analiz kullanılarak araştırma bulguları katılımcı görüşlerinden yapılan doğrudan alıntılarla desteklenmiştir. 
Çalışma grubu, Çağdaş Drama Derneği (ÇDD) İstanbul Şubesi'nde yaratıcı drama eğitmenliği programına katılan 3. ve üst aşamalardan oluşan 3'ü erkek 10'u kadın, toplam 13 kişinin gönüllü katılımı ile oluşturulmuştur. Proje katılımcı sayısı 13 olmasına rağmen çeşitli sebeplerden dolayı genel değerlendirmeye 9 kişi katılmıştır. Uygulama öncesi grubun yaratıcı drama bilgisi ve deneyimi olduğu için grupla bir ön hazırlık çalışması gerçekleştirilmemiştir. Çalışma ÇDD İstanbul şubesinin ikinci katında, yeterli 1sı ve 1şı̆̆a sahip, zemini mineflo kapl1, 68 m2'lik yaratıcı drama yapmaya uygun geniş salonda uygulanmıştır.Yaratıcı drama uygulamaları, 06.04.2012 - 28.04.2012 tarihleri arasında haftada iki gün Cumartesi- Pazar akşam 18:00-21:00 saatleri arasında toplam 24 saat olarak uygulanmıştır.

\section{Bulgular}

Çalışma kapsamında değerlendirilen veriler, öntest-sontest sonuçlarına ilişkin bulgular ile atölye ürünleri, katılımcı görüşleri ve lider gözlemlerine ilişkin bulgular olmak üzere iki başlık altında ele alınmıştır.

\section{1. Öntest- Sontest Sonuçlarına İlişkin Bulgular}

Katılımcılardan elde edilen uygulama öncesi ve sonrasında gerçekleştirilen öntest sontest sonuçları; "Beden Kavramına İlişkin Bulgular”, "Dans Kavramına İlişkin Bulgular” ve Yaratıcı Drama ve Beden Farkındalığına İlişkin Bulgular” adlı üç başlık altında değerlendirilmiştir.

\subsection{BedenKavramına İlişkin Bulgular}

Çalışma kapsamında katılımcılara, beden kavramına ilişkin olarak şu sorular sorulmuştur: "Beden kavramının size çağrıştırdığı 3 ögeyi önem sırasına göre yazınız. İnsan bedenini 3'e bölerek önem sırasına göre sınıflandırınız.Duygularınızı ifade ederken bedeninizi kullanıyor musunuz?” Katılımcıların yanıtlarına ilişkin bulgular Tablo 1'de gösterilmiştir.

Tablo 1. Beden Kavramı ile Illgili Sorulara Verilen Yanitlar

\begin{tabular}{|c|c|c|c|}
\hline Tema & Alt Temalar & Uygulama Öncesi & Uygulama Sonrası \\
\hline \multirow{3}{*}{$\begin{array}{l}\text { Beden kavramı } \\
\text { ile ilgili sorular }\end{array}$} & $\begin{array}{l}\text { Beden kavramının en } \\
\text { önemli } 3 \text { ögesi }\end{array}$ & $\begin{array}{l}\text { Sağlık, ifade, varoluş, işe yararlılık, } \\
\text { yaratma }\end{array}$ & $\begin{array}{l}\text { Denge, çoğalma, iletişim, } \\
\text { üretim, kontrol }\end{array}$ \\
\hline & $\begin{array}{l}\text { İnsan bedenini } 3 \\
\text { bölümde sinıflandırma }\end{array}$ & Baş, gövde, kol ve bacaklar & Omirilik, sırt, ağırlık merkezi \\
\hline & $\begin{array}{l}\text { Duyguların ifadesinde } \\
\text { beden }\end{array}$ & Evet & Evet \\
\hline
\end{tabular}

"Beden kavramının çağrışım yaptığı üç ögeye" verilen uygulama sonrası yanıtlarda beden, bir ifade aracı, üretimin gerçekleştirildiği alan ve dengeyi oluşturan ağırlık merkezine sahip yapı, olarak görülmüştür. Çalışma sürecinde, katılımcılar bedenlerindeki katılı̆g fark etmişler ve daha fazla hareket etmeye ihtiyaç duyduklarını dile getirmişlerdir.

“İnsan bedenini üçe bölerek önem sırasına göre yazınız.” sorusuna uygulama öncesi ve sonrası verilen cevaplar arasında baş, gövde, kollar ve bacaklar yer almıştır. Fakat uygulama sonrası ağırlıklı olarak, omurilik, 
ağırlık merkezi, sırt cevapları verilmiştir. Proje sürecinde katılımcılar, ağırlık merkezi ile bedenlerini kontrol etmenin farkına varmışlardır ve bu farkındalık yanıtlarına da yansımıştır.

"Duygularınızı ifade ederken bedeninizi kullanıor musunuz?" sorusuna katılımcıların hepsi hem uygulama öncesi hem sonrası evet cevabını vermişlerdir. Bazı katılımcılar uygulama sonrası bedenlerini, daha rahat ve daha aktif kullanmaya başladıklarını belirtmişlerdir.

\subsection{Dans Kavramına İlişkin Bulgular}

Çalışma kapsamında katılımcılara, dans kavramına ilişkin olarak şu sorular sorulmuştur: "Dans etmenin tanımını yapar mısınız? Dans etmenin sizin için anlamı nedir?” Dans ederken olması gereken en önemli üç bileşeni yazınız. Katılımcıların yanıtları Tablo 2'de gösterilmiştir.

Tablo 2.Dans kavramı ile İlgili Sorulara Verilen Yanıtlar

\begin{tabular}{|c|l|l|l|}
\hline \multicolumn{1}{|c|}{ Tema } & \multicolumn{1}{|c|}{ Alt Temalar } & \multicolumn{1}{c|}{ Uygulama Öncesi } & \multicolumn{1}{c|}{ Uygulama Sonrası } \\
\hline & Dans etmenin tanımı & Müzik ile hareket & $\begin{array}{l}\text { Bedeni keşfetme, bedenle } \\
\text { iletişim, ifade aracı }\end{array}$ \\
\cline { 2 - 4 } & $\begin{array}{l}\text { Dans etmenin katılımcı için } \\
\text { anlamı }\end{array}$ & $\begin{array}{l}\text { Eğlence, mutlu olma, rahatlama, } \\
\text { özgürlük }\end{array}$ & $\begin{array}{l}\text { Arayış, keşfediş, dişa vu- } \\
\text { rum, üretim, özgürlük }\end{array}$ \\
\cline { 2 - 4 } $\begin{array}{c}\text { İlgili Sorular } \\
\text { navramı ile }\end{array}$ & Dansın en önemli üç bileşeni & $\begin{array}{l}\text { Müzik, mekân, estetik, hareket, } \\
\text { uyum, arkadaş, performans } \\
\text { kaygısı gütmemek }\end{array}$ & $\begin{array}{l}\text { Ritim, beden, } \\
\text { devinim,özgürlük }\end{array}$ \\
\hline
\end{tabular}

"Dans tanımlarının” içinde yer alan "müziğe kendini bırakmak", "müzik ve ritim eşliğinde devinmek" cevapları, uygulama sonrasında; "bedenle iletişim kurmak", "bedenin keşfi”, "bedene izin vermek", "ifade aracı" olarak değişmiştir. Böylece katılımcılar dansı, müzikli eğlencenin dışında, bedeni tanıma, bedenle iletişim kurma biçimi olarak değerlendirmişlerdir.

"Dans etmenin sizin için anlamı nedir?” sorusunda "özgürlük" cevabı hem uygulama öncesi hem de uygulama sonrası verilen yanıtlar arasındadır. Katılımcılar sürecin başında dans etmeyi eğlence, mutlu olma, rahatlama olarak tanımlarken, sürecin sonunda dansın bir arayış, bir keşfediş, üretim ve dışa vurum süreci olduğu fikrine ulaşmışlardır.

"Dans ederken olması gereken üç bileşen" sorusuna katılımcıların uygulama sonrası, uygulama öncesi bileşen olarak yazdıkları, performans kaygısını tekrar dile getirmedikleri, eğlence yerine bedeni tanıma, arayış, huzur gibi bileşenleri yazarak, dansı yalnızca eğlenme aracı olmaktan çıkardıkları görülmüştür.

\subsection{Yaratıcı Drama ve Beden Farkındalı̆̆ına İlişkin Bulgular}

Çalışma kapsamında katılımcılara, yaratıcı drama ve beden kavramına ilişkin olarak şu sorular sorulmuştur: Rol oynama ve doğaçlama esnasında bedeniniz kaçıncı sırada yer alıyor? Yaratıcı drama çalışmalarında sizce bedenin önemi nedir? Beden farkındalığınızın gelişmesi, yaratıcı drama performansınızın gelişmesini nasıl etkiler? Yaratıcı drama performansınızın gelişmesi, beden farkındalığınızın gelişmesini nasıl etkiler? Katılımcıların yanıtlarına ilişkin bulgular Tablo 3'te gösterilmiştir. 
Tablo3. Yaratıcı Drama ve Beden Farkındalı̆̆ı ile Ilgili Sorulara Verilen Yanıtlar

\begin{tabular}{|c|c|c|c|}
\hline Tema & Alt Temalar & Uygulama Öncesi & Uygulama Sonrası \\
\hline \multirow{4}{*}{$\begin{array}{l}\text { Yaratıcı Drama } \\
\text { Kavramı ve Beden } \\
\text { Farkındalığı ile İlgili } \\
\text { Sorular }\end{array}$} & $\begin{array}{l}\text { Doğaçlamada beden kaçıncı } \\
\text { sırada }\end{array}$ & Birinci & Birinci \\
\hline & $\begin{array}{l}\text { Yaratıcı dramada bedenin } \\
\text { önemi }\end{array}$ & Yardımcidır & Temeldir \\
\hline & $\begin{array}{l}\text { Beden farkındalı̆̆ının } \\
\text { gelişmesi yaratıcı darama } \\
\text { performansını nasıl etkiler? }\end{array}$ & Anlatıma etki eder & $\begin{array}{l}\text { Bedeni tanımada ve özgürce } \\
\text { ifade etmede etki eder }\end{array}$ \\
\hline & $\begin{array}{l}\text { Yaratıcı drama performansının } \\
\text { gelişmesi beden farkındalığını } \\
\text { nasıl etkiler? }\end{array}$ & $\begin{array}{l}\text { Bedenin kontrollü } \\
\text { kullanımına etki eder }\end{array}$ & $\begin{array}{l}\text { Bedenin aktif kullanımı, } \\
\text { farkındalık getirir. }\end{array}$ \\
\hline
\end{tabular}

"Rol oynama ve doğaçlama esnasında bedeniniz kaçıncı sırada yer alıyor?” sorusuna katılımcıların çoğu birinci sırada cevabını verirken, bazıları konuşmadan sonra ikinci sırada diye yanıtlamışlardır. Uygulama sonrası bedenin birinci sırada yer aldığını yazan bazı katılımcılar, sürecin sonunda aslında kendileri için şimdiye kadar ikinci sırada yer aldığını, fakat atölyelerden sonra bu sıralamanın değiştiğini, bazıları ses, mimik ve bedenin tümünü bir arada kullandıklarını ve söz olmadan da pek çok şey anlatılabileceğini, bedenin dili çözüldüğünde, rol oynamalarda da çözülmenin, rahatlamanın olacağını yazmışlardır.

“Yaratıcı drama çalışmalarında sizce bedenin önemi nedir?”sorusuna verilen uygulama öncesi cevaplarda sekiz katılımcı bedenin yardımcı olduğunu düşünürken, uygulama sonrası temel olduğunu belirtmişlerdir. Yaratıcı drama atölyelerinde yapılan doğaçlamalarda kendini rahat hissetmediğini söyleyen bazı katılımcılar, sözsüz doğaçlamada kendilerini daha iyi ifade ettiklerini ve özgür hissettiklerini dile getirmişlerdir.

“Beden farkındalığınızın gelişmesi, yaratıcı dramadaki performansınızı nasıl etkiler?” sorusu, uygulama sonrası deneyimledikleri devinim, dans ve beden farkındalığı çalışmaları ile soruda, yaşadıkları deneyimlerden yola çıkarak detaylı olarak yanıtlanmış ve katılımcılar için yeni bir anlam kazanmıştır. Katılımcıların bedenlerini fark edip rahat devinmeleri, yaratıcı drama sürecinde yer alan doğaçlama, rol oynama ya da 1sınma oyunlarında katılımcılara kolaylık sağladığı gibi aynı zamanda bedenleriyle gerçekleştirecekleri imgesel anlatımlarada katkı sağlar.

"Yaratıcı drama performansınızın gelişmesi, beden farkındalığınızın gelişimini nasıl etkiler?" sorusuna verilen cevaplarda, bazı katılımcılar her ikisinin de birbirine katkı sağlayacağını düşünürken bir katılımcı, bu soruya net bir yanıtı olmadığını yazmıştır. Yaratıcı drama ile başlayan üretme ve yaratma sürecinin beden farkındalığına olumlu yansıdığı dile getirilmiştir. Fakat 2 katılımcının cevapları arasında beden farkındalığının gelişmesinin yaratıcı dramaya daha fazla katkı sağlayacağı yer almaktadır. 


\section{Atölye Ürünleri, Katılımcı Görüşleri ve Lider Gözlemlerine İliş̧kin Bulgular}

Çalışma kapsamında kullanılan diğer veri toplama araçlarından ulaşılan veriler "Atölye Ürünlerine İlişkin Bulgular", "Katılımcıların Duygu ve Düşüncelerine İlişkin Bulgular" ve "Lider Gözlemlerine İlişkin Bulgular" başlıklarında değerlendirilmiştir.

\subsection{Atölye Ürünlerine İlişkin Bulgular}

Atölye değerlendirmeleri esnasında katılımcılardan sıklıkla şiir yazmaları istenmiştir. Şiir; duyguların, düşüncelerin sözcüklerle anlatımıysa dans da duyguların ve düşüncelerin beden aracılığ 1 ile dışa vurumudur. Her iki sanat türünde de söz konusu olan duyguların ve düşüncelerin anlatılmasıdır ki; kişinin beden dilini etkin olarak kullanmasının altında sözcüklerin yetersizliği yatmaktadır. Şiir de düz anlatımla sözcüklerin yetmediği yerde imgelerin devreye girmesi ile bir üst dil oluşturarak duygu ve düşünceleri aktarma amacı taşımaktadır. Bu sebeple katılımcılar atölye değerlendirmelerinde birkaç kez şiir yazmışlardır.

Birinci oturumda katılımcılar güneşi selamlama egzersizinden yola çıkarak doğaçlama hazırlamışlardır (Andrews, 2002). Atölye sonunda katılımcılar değerlendirme olarak şiir yazmışlardır. Devinimin gündelik yaşantılarındaki eylemlerden ve doğadan geldiğini belirtmişlerdir. Katılımcılardan ilk oturuma gelmeden önce kişisel dans tarihlerini yazmaları istenmiş, yazılanlar toplanmış; fakat atölye sürecinde değerlendirilmemiştir. Yalnızca geçmişlerine dönük dans deneyimlerini ve o anki duygularını hatırlamaları amaçlanmıştır (Türkoğlu, 2009). İkinci oturumda değerlendirme, canlandırma olarak alınmıştır. Etkinliklerde katılımcıların yazdıkları 11 kelimelik şiir (Elfchen), çizdikleri şekiller ve ritim çalışmasında hazırladıkları performans, verilen temaları doğaçlamada birleştirerek kullanabildiklerini göstermiştir.

Üçüncü oturumda katılımcıların, ikinci oturum sonunda kendilerine verilen gözlemi yaparak atölyeye hazırlıklı geldikleri görülmüştür. Bu ödevde yer alan sorulara göre yaptıkları gözlemleri etkinlikte hatırlamış ve slogan şeklinde bir cümle yazmışlardır. Yazdıkları cümlelere üçüncü oturumda yer verilmiştir. Zihinlerindeki beden imgeleri ve gerçek beden hallerini çizimlerle karşılaştırmışlardır (Tunç, 2007). Katılımcıların ara değerlendirmede bedenlerine haksızlık ettiklerini, bedenlerini sevdiklerini, bedenleriyle yüzleştiklerini, bedenlerini yeni tanıdıklarını belirten cümleler yazdıkları görülmüştür.

Dördüncü oturumda kendilerine okunan metin sonrasında, metindeki fark etme sürecini yaşayıp yaşamadıkları ve kendi bedenlerini kişisel yaşamlarında ne zaman fark ettikleri sorulmuştur. Bazı katılımcılar metindeki süreci yaşamış ve metindeki hareket eden kız gibi zaman zaman hareket etmişlerdir. Bir diğer etkinlikte dinletilen müziklerin kendilerinde oluşturduğu duyguları (telaş, kalabalık, mutluluk, tedirginlik, güven, gençlik, başlangıç, tapınak, hamam, köy düğünü, hayat, gelgit, deşarj, kara kalabalık, kelebek, boşalma, sevgi ve ayrılık... v.b. gibi.) yazmışlardır. Üst üste dinletilen beşşarkının bazı katılımcıları rahatsız ederken bazılarına özgürlük hissi verdiği, alınan sözlü değerlendirme ve gözlemle tespit edilmiştir. Bir diğer etkinlikte ise bedenlerine eklenen organlar arasında yer alan kanat, katılımcılarda özgürlük hissi yaratmış ve katılımcılar kanatlarını bırakmak istememişler, maymun kollarını kendi kollarının yanında taşımak ağır gelmiş, antenlere sahip olmak algılarını açmış, vicdan olarak bir organları olduğunu düşünmek ve onları istedikleri yere koymak onlara farklı bir deneyim yaşatmıştır. Vicdanı kimi alnının ortasına, kimi ayak tabanına, kimi gamze olarak yüzüne yerleştirmiştir. Yine bir diğer etkinlikte katılımcılara iletişim kurarken kullanacakları organlar verilmiş ve yalnızca o organları kullanarak verilen duruma göre hareket etmelerinin katılımcıları kısıtladığı, fakat denemekten vazgeçmedikleri ve keyif aldıkları gözlemlenmiştir.

Beşinci oturumda katılımcılar yere yapıştırılan adımlar üzerinde yürüyerek, belirlenen adımlar dışında yere basmamışlar, karışık bir düzen olduğu için önce algılamalarına yönelik bu adımlar üzerinde yürüme 
çalışması yapmışlar, alıştıktan sonra birkaç kez üzerinde yürümüşlerdir. Adımları algılamalarının zaman aldığı görülmüş̧ür. Adımlar üzerine basarak, öncesinde çalışılan ağır çekim hareketleri (slow motion) parti doğaçlaması ile seyirlik bir performansa dönüşmüştür.

Altıncı oturumdaki hacıyatmaz etkinliğinde katılımcıların genelde rahat olduğu, fakat bazılarının tedirginlik yaşadığı gözlemlenmiştir. Bedenleriyle isimlerini yazarak, isimlerinin harflerini oluşturan hareketlerini gruplarındaki eşlerine öğretip sergilemişlerdir. Akıcı performanslar ortaya çıktığı görülmüştür. Bir sonraki etkinlikte, harflerin bedenlerinde uyandırdığı duyguyu göstermeleri farklı bir deneyim yaşatmıştır. Sözgelimi “ $T$ ” harfi sıçrama, itme, parmak ucuna yükselme gibi devinimlerinin oluşumuna neden olmuştur. Kırmızı, siyah, yeşil ve beyaz renklerine bakıp yazdıkları kavramlar ve eylemler (kına gecesi, evlenmek, utanç, saklanmak, gece, uyumak, şaman, büyü yapmak, gizem, geri ileri gitmek, çimen, paylaşmak, mutluluk, uçmak, sonsuzluk, maden, derin nefes al, öfke, kavga, umutsuzluk, başkası da mümkün, merak, dona kalmak, karanlık, asil, şafak, izlemek, 1 Mayıs, gitmek, umut, dans et, kaçmak, özgürlük... v.b. gibi.) üzerinde ara değerlendirme alındığında, renklere bakınca oluşan ilk duygularını yazanların yanı sıra düşünüp farklı kavramlar bulan katılımcılar olduğu görülmüştür. Doğaçlama için verilen cümlelerle katılımcılar, hem o cümlenin rengini bulmuş, hem de renkler için yazılan kavramlardan ikisini seçerek doğaçlamalarında kullanmışlardır.

Yedinci oturumda doğaçlama için verilen fotoğrafların kendilerinde yarattı̆̆ı duyguyu bulmuşlar, doğaçlama başlangıcında fotoğraflardaki pozları kullanmışlardır. Pozları oluşturma konusunda zorluk çekmemişlerdir. Fakat kontakt doğaçlama çalışmasındaki hareketleri yaparken biraz zorlandıkları görülmüştür. Hareketleri algıladıktan sonra devinmelerinin daha rahat olduğu gözlemlenmiştir. Lifting çalışmasında özellikle tekniği anlamak için zamana ihtiyaç duyulduğu fark edilmiştir. Birbirleriyle temas etme konusunda genelde sıkıntı yaşamadıkları gözlemlenmiştir. Kadın, erkek ayrımı yapmadan bedenleriyle birbirlerine temas etmişler ve teması hiç koparmamışlardır. Yalnız iki kişi sonradan rahatsız olduğunu söyleyerek etkinliği oturarak izlemiştir.

Sekizinci oturumda Afrika dansına ait hareketler - miş gibi yapma ile gösterilmiştir. Sözgelimi çamaşır yıkayıp asılmıştı. Böylece hareketleri daha rahat yapabilmişlerdir. Amazon yerlilerinin dövme şekillerindeki çizgileri kullanarak konumlarını belirlemişler ve bu şekillerin ne olabileceğini ve kendilerinde nasıl bir duygu yarattığını düşünerek doğaçlamalar hazırlamışlardır (Levi-Strauss, 1992). Akira Kurosawa'nın“Dreams” filmindeki “Su Değirmenleri” bölümünde izledikleri cenaze töreninin öncesini ve sonrasını canlandırmışlardır (Kurosawa, 1990). Katılımcılara filmdeki müzik çalınmamış ve müziklerini kendilerinin yapmaları istenmiştir. Enstrümanlarını da mevcut materyallerden kendileri icat etmişlerdir. Hem cenazedeki müziğin ezgisini hatırladıkları hem de yaratıcı enstrümanlar yaptıkları görülmüştür. Sözgelimi doktor eldivenine çay kaşıklarını bağlayarak enstrüman olarak kullanmışlardır. Ayrıca bir önceki oturumda çalışılan kontakt doğaçlamadaki birbirini sırtında taşıma çalışmasını doğaçlamaya aktardıkları gözlemlenmiştir. Sonrasında istasyon çalışmasında kendi yarattıkları topluluğun hikâyesini yazmış, sembollerini ve maskelerini yapmış ve performans hazırlamışlardır. Türler arası geçişin doğaçlamaların odak noktası olduğu görülmüştür. Bir grup beslenme sonrası türlerin dönüştüğünü gösterirken, diğer grup türler arası geçişin kolay olmadığını göstererek, o toplumda geçişi anlatan ritüeli gerçekleştirmiştir. Son grup ise doğum temasını ele alıp türlerin birbirlerine geçişini maskelerle anlatmıştır.

\section{2. Katılımcıların Duygu ve Düşüncelerine İlişsin Bulgular}

Projenin değerlendirmesinde katılımcılar önce süreci zihinlerinde oluşturdukları üçgenler üzerinde değerlendirmişler ve devinmişlerdir. Ardından kendilerine verilen kâğıtlara üçgenlerini çizip sürecin öncesi, sürecin içinde olma anı ve sürecin sonrası için cümleler yazmışlardır. 
Tablo4. Katılımcıların proje uygulamasına dair genel değerlendirmedeki duygu ve düşünceleri

\begin{tabular}{|c|c|c|c|}
\hline Tema & Alt Temalar & Duygu ve Düşünce & f \\
\hline \multirow{9}{*}{$\begin{array}{c}\text { Genel } \\
\text { Değerlendirme }\end{array}$} & \multirow{3}{*}{ Atölye Öncesi } & Merak & 3 \\
\hline & & Heyecan & 2 \\
\hline & & Uygulama isteği & 4 \\
\hline & \multirow{3}{*}{ Atölye Süreci } & Devinme & 4 \\
\hline & & Arayış & 3 \\
\hline & & Sürpriz & 2 \\
\hline & \multirow{3}{*}{ Atölye Sonras1 } & Güven & 2 \\
\hline & & Beden farkındalığı geliştirme & 5 \\
\hline & & Haz & 2 \\
\hline
\end{tabular}

Süreç, lider adaylarına olumlu katkı sağlamıştır. Katılımcılar, yapılan çalışmaların hem kendilerine kişisel gelişim açısından fayda sağladığını hem de sonrasında lider olarak yapacakları çalışmalara katkı sağlayacağını dile getirmişlerdir.

Sözel olarak alınan değerlendirmede ise aşağıdaki görüşler belirtilmiştir:

- K1: Başlarken heyecanlı ve çelişkiliydim. Kendimi geri çekmedim. Ürettim. Çıkarımlarda bulundum. Katılımcılar üretken ve yaratıcıydı, beni şaşırttılar. Cinsiyet ayrımım yok. 2000 yılından beri yaptığım çalışmaların etkisiyle, beden benim için yalnızca bir et parçası.

- K2: İlk başta meraklı ve kaygılıydım; çünkü sadece dansa dönük bir çalışma olacağını sanmıştım. Merakım hep sürdü. Hareket ve enerji buldum. Bedenimi rahat kullandım. Sembolik bir şeyler bulmak beni zorladı. Daha güvenli ayrılıyorum. Doğaçlama yaptığımı hissetmedim. Bu nedenle gerilmedim, rahattım.

- K3: Umut ve beklenti içinde geldim. Kendi bedenimle ne yapabileceğimi merak ediyordum. Beklentim karşılandı. Yeni bir şeyler görmeyi umut ettim. Çok keyif aldım. Bedenimin daha çok farkındayım. Çok şey kattı.

- K4: Heyecanla geldim. Klasik anlamda dans sandım. Katılımeı endişem vardı. Hepsi grupla kırıldı. Süreç çok yaratıcıydı. Sürprizlerle doluydu. Ceplerimi doldurdu. Enerjisi yüksekti. Bedenimle yapabildiklerimi ve yapamadıklarımı keşfettim. Daha ince olduğumu fark ettim.

- K5: Merak ederek isteyerek geldim. Bedenimi iyi kullanmadığımı düşünüyordum. Yaratıcı drama aşamalarında bazı gruplarda rahatken bazı gruplarda “yapamam”lara dönüşüyordum. Bedenimi zorlamam, yapmam gerekiyor diye düşündüm. Hiç olmadığım kadar rahattım ve kendime güvendim. Denedim. Bedenimi daha rahat kullandığımı düşünüyorum. 
- K6: Her şeye hazırdım. Teslimiyet içinde geldim. 1. Aşamada kolum çıktığı için endişeliydim. Etkinlikte zorlanınca korktum. Ham olduğumu fark ettim. Bedenimle ilgilenme ihtiyacı hissediyorum. Bedenimi fark ettim. Bedenimi yeni keşfediyorum. Yapmadığım şeyleri yaptım.

- K7: Mutluydum. Büyük devrimlerin beden keşfiyle olacağını düşünüyorum. Cinsellik yaşamın bütününde var. Sadece birleşmede değil. Son oturumda cinsiyeti kaldırınca mülkiyetle birlikte her şey ortadan kalktı. Beden farkında kullanabileceğim birçok nüve elde ettim ve bunları kadın çalışmalarında kullanacağım. Aklı ve bedeni ayrıştırıyoruz. Oysa akıl, beden ve duygu bir arada. Grup olarak rahattık. Grupla birlikte heyecanlıydık. Duygum coşku olarak açığa çıktı hep. Bazen uyaranlar fazla geldi. Zaman uzadı. İyi bir kapı açtı̆̆ını düşünüyorum.

- K8: Birçok açıdan ilkti. Senin yaptığına vakıf olduğunu hissettim. Bu güven verdi bana. Projenin bütünlüğü vardı. Tahmin etmeye çalışmaktansa izini sürmeyi tercih ettim. Sınırları zorladığımı görmek hoşuma gitti. Aşamalarda bir şey yaparken tedirginlik verici bir şeyler vardı. Bedene dokunmadan kazanıma ulaşılmaz. Bedene yönelik atölyeler yapılmalı. Çok mutlu oldum.

- K9: Dans etmeyi seviyorum. Dans bende adımı olan bir şeydi ya da içinden geldiği gibi tepinmekti. Kafamda dans öğrenilen bir şeydi. Dansa giden arayış ve yeni denemeler güzeldi. Adım adım gidip üretime taşımak güzeldi. Bu çalışma dans kurslarına taşınabilir ve bu yöntemle dans öğretilebilir. Özel etkinlikler vardı. Kontakt doğaçlamadaki çalışma oyunsu süreçlere aktarılabilirdi.

\subsection{Lider Gözlemlerine İlişkin Bulgular}

Proje süreci boyunca gerçekleştirilen lider gözlemleri sonucunda aşağıdaki bulgular elde edilmiştir:

Uygulamalar sırasında, ısınma egzersizlerinin katılımcıları sonraki etkinliklere hazırladığı, katılımcıların bedenlerinin açıldığ 1 ve etkinliklerde daha rahat hareket ettikleri görülmüştür. Isınma egzersizinin yeterince yapılması, araştırmalarını ve denemekten korkmadan devinmelerini sağlamıştır. Katılımcıların kendilerini rahat hissetmeleri için ısınma egzersizleri ilk atölyede, çember düzeninde yapılmamıştır. İkinci atölye ve sonrasında egzersizler her zaman çemberde yapılmıştır. Katılımcılar birbirlerini görerek egzersizleri yapmaktan rahatsız olmamışlardır.

İlk atölyede tanışmaya yönelik isim çalışması yapılmamış, katılımcıların kendi bedenleri ve diğerlerinin bedenleriyle tanışması önemsenmiş, ikinci atölyede isim çalışmasına yer verilmiştir. $\mathrm{Bu}$ durum katılımcıları rahatsız etmemiş tam tersine, bedenleri ile kurdukları iletişim sonucu birbirleriyle daha sıcak iletişime geçmişlerdir.

Birinci oturumda kısıtlanmış hareketlerle verilen temadan doğaçlamaya gidilmesi katılımcıları yaratıcı kılmıştır. Belirlenen birkaç hareketle de bir konunun anlatılabilirliğini deneyimlemişler ve hiç zorluk çekmemişlerdir. Yaratıcı doğaçlamalar sergilemişlerdir.

Ödev olarak verilen kişisel dans tarihi ile ilgili yazı yazmaları atölye sürecinde kullanılmamış yalnızca katılımcıların, ilk dans ettikleri zamanı ve neler hissettiklerini hatırlamaları için verilmiştir. Bazıları ilk dans ettikleri zamanı hatırlamasalar da anımsayabildikleri ilk danslarını ve o dönemi yazmışlardır. Birlikte oldukları kişilerle keyifli süreçler yaşadıklarını dile getirmişlerdir.

Atölye sonunda kazanımlara ulaşıldığını lider her defasında değerlendirmede ortaya konan ürünlerle tespit etmiştir. Bazı atölyelerin değerlendirilmesi doğaçlama olarak alınmıştır. Bazı atölyeler de ise şiir yazmışlar, resim çizmişler ya da oyun oynamışlardır. Yazma süreci, katılımcıları, devinimden yaratıcı yazma sürecine taşımıştır. 
Her atölye sonrası katılımcılar daha rahat hareket eder hale gelmişler ve bedenlerinin hareket etmeye ihtiyacı olduğunu yeniden fark ettiklerini dile getirmişlerdir. Uygulama sonrası spora başlamak istediğini ya da dansa başlayacağını dile getirenler olmuştur. Beden farkındalıkları, beden hâkimiyetleri gelişmiştir. Kendilerini ifade etmek için bedenlerinin daha özgürce hareket etmesine izin vermişlerdir. Cinsiyet ayrımı yapmamışlardır. Kontakt doğaçlama esnasında bedenlerinin temas etmesinden rahatsız olmamış, doğaçlamalarında kendiliğindenlik ile birlikte rahat bir akış gerçekleşmiştir. Teması bir yere kadar sürdürebilen iki katılımcı, süreçte kendini yer yer geri çekip diğerlerini seyretmiştir.

Yedinci oturumda yapılan etkinlikte, kese kâğıdını başlarından geçirmek suretiyle kollarını bedenlerinden ayırmadan ve görmeden sınırlandırılmış alanda devinmişlerdir. Bazı katılımcılar bu kısıtlanmışlıktan rahatsız olmuştur. Özellikle kese kâğıdı farklı çağrışımlara neden olduğu için kendilerini huzursuz hissetmişlerdir. Bu çağrışımlar arasında, iktidar, sistem, tutsaklık, kısıtlanmışlık yer almaktadır. Atölyelerde çok rahat hareket eden bir katılımcı, kese kâğıdı içinde asgari düzeyde hareket etmiştir. Bazı katılımcılarsa kendilerini rahat ve özgür hissetmişlerdir. Katılımcılardan biri etkinliğe iki kez katılmış ve her ikisinde de kendini huzurlu hissettiğini, evrende tek başına olduğunu ve istediği gibi davrandığını, uçtuğunu, yüzdügünü, bir sürü filme girip çıktığını dile getirmiştir. Katılımcılar kısıtlanmış mekânda kese kâğıdı olmadan hareket ederken birbirleriyle çok ilişkilenmezken, kese kâğıdı taktıklarında birbirleriyle temas etme, birbirlerine yakın durma ihtiyacı hissetmişlerdir.

Etkinliklerde ortaya koydukları ürünleri, doğaçlamada tekrar kullanmışlar ve verilen tema ile ürünleri birleştirerek yaratıcı performanslar sergilemişlerdir. Böylece kendi ürettiklerini bir araya getirerek yeniden üretime gidebilmişlerdir. Yine duygu ve düşüncelerini açığa çıkaran etkinlikler sonrası, bu verileri bedenlerine aktarmışlar ve seyirci katılımcılar performans sergileyen katılımcıların anlatmak istediklerini genelde tahmin edebilmişlerdir.

Beden farkındalığı üzerine yapılan üçüncü oturumda katılımcılar, zihinlerindeki beden imgelerinin daha geniş olduğunu, sonrasında eşlerinin kalıplarını çıkarması sonucunda fark etmişlerdir. Bize dayatılan daha zayıf olma düşüncesinde olduklarını, günümüzde bedenlerin nesne durumuna geldiğini, herkesin tek tip olduğunu, sistemin beden üzerinden insanları yönlendirdiğini söylemişlerdir.

Oturumlarda doğaçlamalar ve performanslar genelde müzik olmadan gerçekleştirilmiştir. Katılımcılar, performans esnasında müzik talebinde bulunmamışlardır. Bir oturumda bilinçli olarak performanslarında müzik kullanılmıştır. Değerlendirmedeki yorumlarında müzik olmadan da rahat devinebildiklerini söylemişlerdir. Bazıları müziğin özgür devinimini engellediğini, bazıları da müzik ile duyguya girmenin kolaylaştığını dile getirmiştir.

Beden Farkındalığı II oturumunda kendi otantik hareketlerini bulup, herkesin birbirinden farklı devindiğini fark etmişlerdir ( $\mathrm{Bu}$ etkinlikte bilinçli olarak müzik kullanılmamıştır ki; duydukları ritme göre bedenleri ezberlerindeki hareketleri yapmasın. Bedenlerinin ezberlerinin bozulmasına önem verilmiştir). Gözleri kapalı devinme etkinliğinde, bazıları özgürce, dışa dönük, bazılarıyla sesten uzak durarak daha kendine dönük hareket etmiştir. Etkinlik sonrası içe dönük hareket edenler, bu durumun yetiştirilme tarzları ile ilgili olduğunu dile getirmiştir.Proje boyunca, katılımcılara etkinlikler aracılığ 1 ile uyaranlar vererek (renkler, nesneler, şekiller, şiirler, fotoğraflar... v.b. gibi) onların her seferinde duygu ve düşüncelerini bedenleriyle aktarmalarına önem verilmiştir. Katılımcılar süreç içinde bu aktarımı gerçekleştirmişlerdir. 


\section{Sonuç ve Öneriler}

Çalışma sonunda, ısınma egzersizlerinin yapılmasının sonraki etkinliklerin daha rahat bir şekilde gerçekleştirilmesini kolaylaştırdığı saptanmıştır. Beden farkındalığının gelişmesi, rol oynama ve doğaçlama esnasında katılımcıların bedenlerini daha kontrollü kullanmasını sağlamıştır. Devinim becerilerinin gelişmesi, rol oynama ve doğaçlamalarda katılımcıları ıraksak düşünceye yönlendirmiştir. Dans becerilerinin gelişmesi ise, rol oynama ve doğaçlama sürecinde hareketlerin daha estetik görünmesine katkı sağlamıştır. Ayrıca katılımcılar, belli bir dansın adımları öğretilmeden, kendilerine has (otantik) hareketleriyle devinmenin de dans olduğunu görmüşlerdir. Doğaçlamalarda söz kullanılmaması katılımcıları beden üzerinden anlatıma yönlendirmiş ve katılımcıların tekrar tekrar denemelerini, keşfetmelerini sağlamıştır. Böylece söz olmadan, yalnızca bedenin kullanımı ile de doğaçlama yapabileceklerini fark etmişlerdir. Ayrıca atölyeler genelinde katılımcılar, doğaçlamalarda kendi iç ritimleri ile müzik olmadan da devinebileceklerini fark etmişlerdir.

Katılımcıların duygu ve düşüncelerini yalnızca sözlerle değil, bedenleriyle devinerek anlatabilme becerileri gelişmiştir. Yapılan etkinlikler ve canlandırmalar, katılımcıların birbirleriyle konuşmadan da iletişime geçebileceklerini göstermiştir. İlk doğaçlamalarda konuşma gereksinimi hisseden katılımcılar, daha sonraki doğaçlamalarda anlatımlarını beden üzerinde rahatça aktarmaya başlamışlardır. Sözün ortadan kalkması ile duygu ve düşüncelerin bedenle aktarımı, katılımcıların kendilerini özgürce ifade etmelerini sağlamıştır.

Tunç (2007)'un ergenlerin beden imgelerini belirlemek için yaptığı çalışması atölyede uygulanarak, katılımcıların zihinlerindeki beden imgesi ile gerçek bedenleri arasında fark olduğunu gördüklerinde, bu çalışma ile aslında bedenlerini sevdiklerini, bedenleriyle yüzleştiklerini, bedenlerini yeni tanıdıklarını ifade etmeleri sağlanmıştır.

Uygulama esnasında atölyelerde katılımcılara farklı alıştırmalar yaptırılmış ve bu alıştırmalardaki hareketlerden yola çıkarak katılımcıların bedenlerinin ezberibozulmuş, alternatif devinmesürecini deneyimleyerek bir duyguyu, bir düşünceyi ya da bir olayı bedenle anlatmanın yolları olduğunu fark etmeleri sağlanmıştır. Böylece doğaçlama esnasında hem verilen hareketleri hem de kendi buldukları otantik hareketlerini sergileme olanağı elde etmişlerdir. Dans ve devinim çalışmalarında yaratıcı dramadan yararlanılması, performans kaygısı gütmeden katılımcıların kendini özgürce ifade etmesi açısından önerilir. Ayrıca dans ve devinim, rol oynama ve doğaçlamalarda çoğunlukla sözel ifadeye dayalı canlandırmalarda daha estetik ve imgesel anlatımların ortaya çıkmasını sağlayabileceği için önerilmektedir.

$\mathrm{Bu}$ çalışma yaratıcı drama eğitimine en az 3. aşamada olup devam eden katılımcılarla gerçekleştirildiği için yaratıcı dramayı tanımaya yönelik hazırlık atölyeleri uygulanmamıştır. Fakat yaratıcı dramayı tanımayan katılımcılarla yapılacak uygulamalar için temel kavramlara yönelik yaratıcı drama atölyeleri yapılması önerilir.

Belirli kalıplar içinde ezberletilerek verilen dans eğitimleri zaman zaman sıkıcı olabilmekte ya da öğrenilmesi zor bir hal almaktadır. Son atölyede Afrika dansı figürleri çalış1ırken -miş gibi yapılarak figürler gündelik yaşantının içinden devinimlerin örnek olarak verilmesi ile aktarılmıştır. Böylece katılımcılar kolay ve keyifli öğrenme sürecini deneyimlemişlerdir. Bu sebeple dans çalışmalarında benzer yöntemlerin denenmesi önerilmektedir. 


\section{Kaynaklar}

Adıgüzel, Ö. (2010). Eğitimde Yaratıcı Drama. Ankara: Naturel Yayıncılık.

Andrews, T. (2002). Büyüsel Dans Teknikleri. (Çev. A. Gorbon) İstanbul: New Age Yayınları.

Can, Ş. (1997). Klasik Yunan Mitolojisi. İstanbul: İnkılap Kitabevi.

Gardner, H. (2004). Zihinsel Çerçeveleri Çoklu Zeka Kuramı. (Çev. E. Kılıç) İstanbul: Alfa Yayınları.

Huizinga, J. (2010). Homo Ludens Oyunun Toplumsal İşlevi Üzerine Bir Deneme. (Çev. M. Ali Kılıçbay) İstanbul: Ayrıntı Yayınları.

Kurosawa, A. (1990). Dreams. Japonya.

Levi-Strauss, C. (1992). Hüzünlü Dönenceler. (Çev. Ö. Bozkurt) İstanbul: YKY

Nietzsche, F. (2002). (Çev. O. Derinsu) Böyle Diyordu. (Çev. M. Ali Kılıçbay) İstanbul: Varlık Yayınları.

Tunç, A. (2007). Ergenlerin Olumsuz Beden İmgelerine Yönelik Geliştirilen Bilişsel-Davranışçı ve Değiştirilmiş Sanat Terapisi Programlarının Etkinliklerinin Karşılaştırılması. Ankara Üniversitesi, Ankara.

Türkoğlu, İ. (2009). Modern Dansta Solo: Koreograf ile Dansçı Kimliği arasında Gidip Gelen Beden. Mimar Sinan Güzel Sanatlar Üniversitesi, İstanbul.

Wenders, W. (2011). Pina. Berlin: Neue Road Movies.

Winnicott, Donald.W. (1998). Oyun ve Gerçeklik. (Çev. S. M. Tura) İstanbul: Metis Yayınları.

Wulf, C. (2009). Tarihsel Kültürel Antropoloji. (Çev. Ö. D. Sarısoy) Ankara: Dipnot Yayınları.

Yaşayan, G. (2009). Beden: Estetikten Arzuya. Felsefe Ekibi Dergisi, Sayı 13. 


\title{
Developing dance Body Movement Skills and Body Awareness With Creative Drama
}

\author{
Bahar Gürey $^{3}$ \\ Ömer Adıgüzel ${ }^{4}$
}

\section{Introduction}

The body is often in focus during the preparation/warm-up and acting stages of creative drama. The body is a kind of instrument and the more a person is aware of his/her body through these processes the better control he/she will have over it. Consequently, one will use his/her body as a communication tool while expressing him/ herself through his/her body because words alone are inadequate to express emotion and thought. The affect of emotion and thought is first reflected in our bodies.

Looking through the perspective of creative drama, which is a group activity, participants conduct both verbal and non-verbal communication, just like in daily life. Spontaneous verbal and physical dialogues in acting determine the beginning, development and conclusion of improvisation within the scope of participants'role. However, throughout this process, participants can become inclined to speak -verbal communication- with less emphasis on physical communication. Concentrating on verbal communication and disregarding non-verbal communication in improvisation can occasionally lead to stagnation, resulting in improvisation that only involves forming sentences.

Adigüzel (2010) argues that creative drama requires action. Considering that action is more important than language and movement exists within the action, it could be said that emphasising movement in improvisation does enrich improvisation itself. That is why, having control of the entire body, which can be defined as the participant using his/her body pre-eminently, allows the person to recognise his/her body and therefore him/ herself. Based on this, it is important for creative drama instructor candidates to focus on the continuity of their bodies in verbal and non-verbal communication and develop movement and motivation, besides working on body awareness. Physical expression of emotions and thoughts gives the person the opportunity to think within movement and discover his/her authentic expression because while moving, the person uses his/her body as a tool of expression.

\section{The Relation Between Dance and Play}

It could be said that the act of primitive humansimitatinghunting and other activity around the campfire each night leads to rituals, however both originate from playing games. This is because some scientists perceived the roots and foundation of playing as an event determined by the abundance of joy for living, while others argued that the need for creatures to play is influenced by the innate talent for imitation, using games as a means of preparation for serious activities in life (Huizinga, 2010). While enacting hunting could be preparation for the hunt tomorrow, it also is a process of enjoyment for both the actor and onlooker. Drama is in one to one relation with imitation, dance, rituals and, of course, culture.

Societies express their own culture with physical movement. Each culture has its own unique structure,

3 Teacher, Contemporary Drama Corporation

4 Assoc. Prof., Ankara University Faculty of Education 
way of living and distinct way of expression. Thus people get reacquainted with themselves as if they look in the mirror. In this context, movement is an important aspect of play. According to Winnicot (1998) the whole existence is constructed on playing. A person is not introvert or extrovert while acting in a play. S/he lives the moment as here and now. S/he is at the intersection of objective and subjective observation. Whether a child or an adult, one can only demonstrate his/her creativity and entire personality while playing, and can only discover oneself when creative. From this perspective it is evident that the process of play is an integral part of movement and that this movement exists in play as a tool of expression. Like playing, dance offers the opportunity of living here and now.

\section{The Relation between Creative Drama and Dance}

With one or moreof artistic disciplines like music, dance, literature, painting, drama and cinema a person is in the process of expressing his/her emotions and thoughts while getting to know him/herself at the same time. Verbal expression is not the only way a person presents works that express him/herself through art. This is because it is impossible to express experiences, associations and emotions with words alone. For art forms that use movement the person can express his/her emotional states as freely as possible. Sometimes a single move could provide a much more powerful expression compared to countless words. According to Pina Bausch, one has to make it felt when words are not enough on certain occasions. She argues that words are inadequate to set something in motion and this is the exact point where dance emerged. What cannot be expressed in words can be manifested in dance (Wenders, 2011).

Act is in the centre of creative drama and this is what sets children and adults in motion because the act is more movement than words. In addition to spiritual relief, physical relaxation may be experienced by using the body and being involved in the actions. Whereas improvisations can contribute to the development of social communication. Because there is no error, or rather mistake, the person can freely express him/herself.

The use of creative drama and dance, which is an art form based on movement, can help people develop themselves in body awareness and movement. Movement makes the body secrete endorphin and this makes the person feel better and more energetic. Because there is no worry about performance, the person has more selfconfidence in his/her movements and seeks his/her own authentic move in the actions. This means of expression has positive implications on the person's daily life. Therefore s/he might become a self-confident person who can easily express him/herself and gain a open perception.

\section{Methodology}

The study group for the project consisted of a total of 13 members of the Contemporary Drama Association, Istanbul Branch(3 males and 10 females), participating in the creative drama instructor training programme, attending level 3 or higher. The project was announced to association members via e-mail and volunteers were selected from enthusiastic persons who could attend the workshops regularly. A preparation session was not scheduled before the application because the group had knowledge and experience on creative drama.

The project was carried out on the second floor of the Contemporary Drama Association, Istanbul Branch in a 68-m2 room of adequate temperature and light, PVC flooring that was suitable for creative drama. Special attention was given to large space for participants to move freely. The project was carried out two days a week, Saturday-Sunday evening between 6PM and 9PM for a period of 24 hours between 06.04.2012 and 28.04.2012.

This project has used the "case study" design from qualitative research design options. Case studies 
are rather suitable to thoroughly investigate a specific case like a programme, a person, an operation, a process, an institution or a social group. Case studies facilitate detailed investigation of the case and provide means of application (Merriam, 2009 trns. Türker, B., 2011). Preliminary test, final test, participant recognition form, participant products (painting, figures, poems), personal dance history and observation assignments, leader's opinion on workshop as participatory observer and video observation footage has been used during the data collection stage of the project. The workshops conducted during the project were executed with creative drama methods and techniques.

\section{Findings}

This section refers tothe following data collection tools; preliminary test, final test, participant questionnaire, workshop productions, the explanation and interpretation of leader observations and general evaluation

\section{General Evaluation}

Table4: Participant's thoughts and feelings about project implementation during general assessment

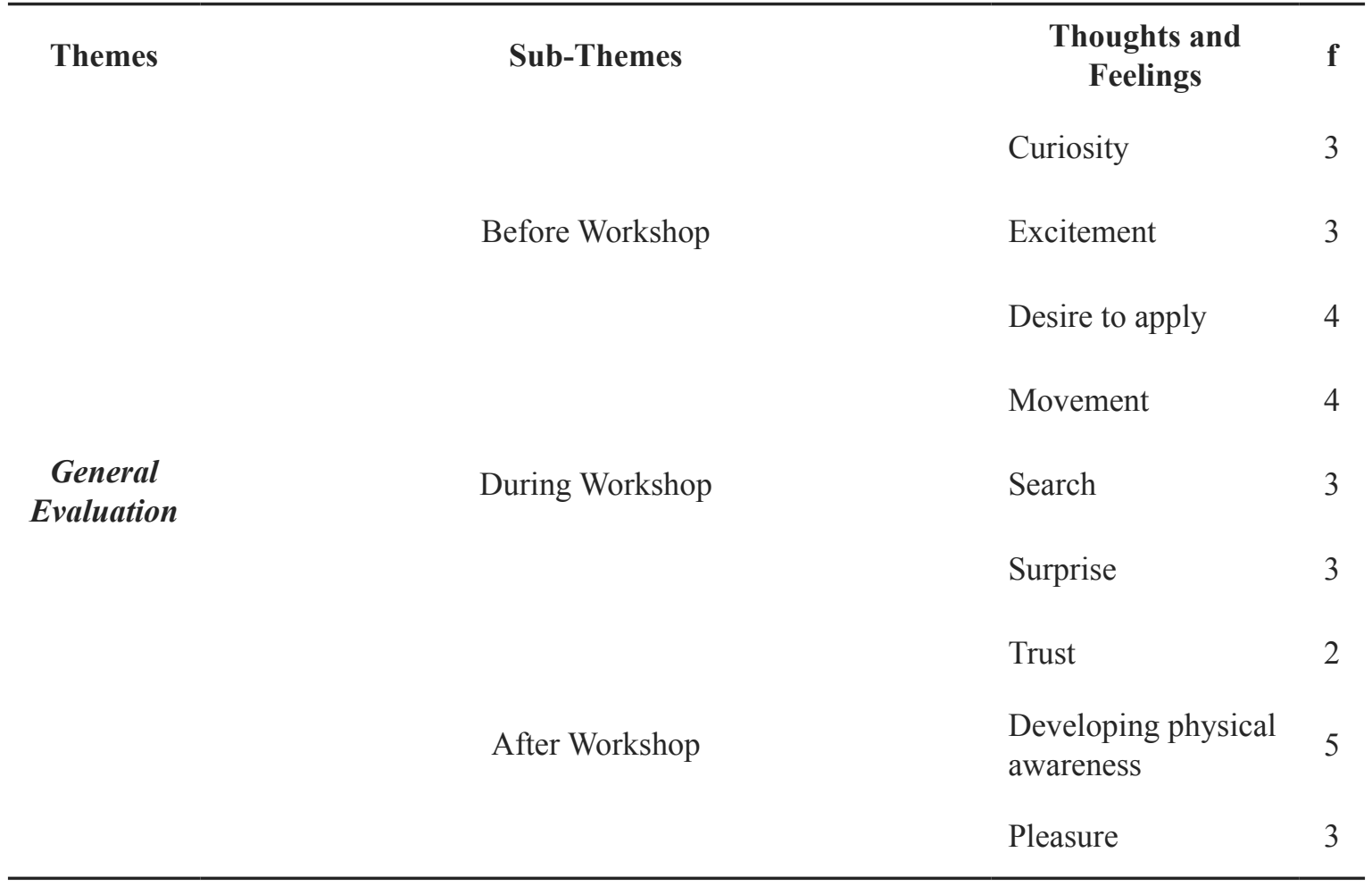

During project evaluation participants first evaluated the process on their mental triangles and then moved. Then, on the sheets of paper provided they drew their triangles and first wrote sentences about the moment of being in the process and after. Participants thought that the performed activities benefited them at a personal level and the work they will carry out as a leader in the future.

Some of the oral evaluations are provided below: 
- K5: I came voluntarily, out of curiosity. I thought I did not use my body properly. In the process of creative drama I was comfortable with some groups but became "no can do" with other groups. I thought I had to force my body. I tried. I believe I am more comfortable in using my body.

- K7: I was happy. I believe great revolutions will come from discovering the body. Sexuality is everywhere in life. Not just intercourse. Removing gender in the final session led to disappearance of everything together with ownership. I gained several cores that I could use in physical awareness and I shall use this for women's studies. We separate the mind and body. Though mind, body and emotion are altogether. We were comfortable as a group. We were excited as a group. My emotions always came out as enthusiasm. Sometimes the stimulants were too much. I believe it has opened new doors.

- It was something new in many ways. I felt that you knew what you were doing. This gave me a sense of trust. The project had integrity. I preferred to follow rather than trying to guess. I liked to see myself push my boundaries. There was something at unease when we were doing something in creative drama. No gain without touching the body.

\section{Results and Recommendations}

The conclusion section of the project implemented with leader candidates from the Contemporary Drama Association was written based on the findings acquired throughout the project. Results have been presented below:

Warm-up exercises led to subsequent events becoming easier. Development of physical awareness made participants use their bodies in a more controlled manner during acting and improvisation. Development of movement skills has directed participants towards a more divergent thought during acting and improvisations. Finally, development of dance skills has made movements look more aesthetic in the process of acting and improvising. What is more, they have realised that using their own authentic movements without being taught the specific moves of a dance, is also dance.

Refraining from speech during improvisation has led participants to express using the body, try repeatedly and discover. Participants thereby realised that it is possible to improvise just by using the body, without any words. Also, throughout the workshops in general participants have realised that it is possible to move based on their own inner rhythm, without any music playing.

Participants' ability to express their emotions and thoughts not just with words, but also by moving their bodies improved. The performances and actings performed have demonstrated that it is possible to communicate without talking Participants who felt the need to talk during first improvisations became increasingly able to use their body to express themselves in subsequent improvisations. Removing verbal expression to use the body to express emotions and thoughts helped participants to freely express themselves.

Tunç's study to determine adolescents' body images was practiced in the workshop and when participants realised a difference between body image in their minds and their real bodies, they expressed that this activity made them love, confront and get to know with their bodies.

Rather than talking a lot during improvisations, participants have realised the importance of the body in preparing improvisations with more elevated imagery. They realised that it is possible to demonstrate creative performances by making the body more active during improvisations.

For the hearing study in the fourth session, participants were asked to listen to a mixed song made of five different overlapped songs and each participant was able to tune in to the most appealing rhythm from this 
complex structure.

Participants' body routines were broken by making use of different movements that were practiced during the sessions. Through experiencing alternative ways of moving participants perceived that there were different ways of expressing a thought or an occasion with the body.

\section{Recommendations}

At the end of the project it is observed that creative drama was an effective method in developing dance, movement skills and physical awareness. It is also understood that movement, dance skills and physical awareness contributes to creative drama, acting and improvisation processes.

Using creative drama for dance and movement exercises is recommended for participants to freely express themselves without being concerned about performance. More so, dance and movement is recommended to accompany occasional sections with plenty of speech in acting and improvisation during creative drama work because it can render expressions more aesthetic and imaginative.

Dance training based on memorising specific patterns can sometimes be boring. Instead, practicing the dance defined on the principle of pretending is recommended for people learning dances originating from movements our daily lives to make the learning process easier and more entertaining by establishing links to the movements in their lives.

Including activities related to dance, movement and physical awareness in creative drama instructor training programmes will lead to improvisation with less talk and more body involvement since participants can display their emotions and thoughts through their bodies.

Individuals who can express oneself with a freely moving body and communicate after social, emotional and physical development will have free thought. The greater the number of people with free thought the closer we are to the philosophy of a society that thinks, questions and criticises. That is why giving more emphasis on dance, movement and physical awareness in creative drama instructor training programmes is recommended. 
EK: 3. ve 5. Oturum Planlar1

\section{Üçüncü Oturum}

Tarih:14.04.2012

Konu: Beden Farkındalığ 1

Grup: Çağdaş Drama Derneği İstanbul Şubesi Katılımcılarından oluşan (Eğitmenlik ve liderlik programında en az 3. aşamayı bitiren katılımcılardan oluşan grup) 13 kişi

Süre: $90^{\prime}+90^{\prime}$

Yöntem: Yaratıcı drama

Teknik: Doğaçlama, rol oynama,

Araç ve Gereç: Kağıt, kalem, boya, CD Player, Müzik (1sınma için şarkılar: Secret Garden -Lotus„Karşı pencere film müziği, Ayub Ogada -Kothbiro-, Fazıl Say- Kara toprak-, Eleni Karaindrou-Ağlayan Çayır ve Eternity and a Day film müzikleri-, Fountain film müziği, Manu Chao- Clandestino-, Marie Boine PersenVuoi vuoi mu-, Trio Joubran-masar-, V for Vendetta film müziği, Ravi Shankar- Improvisation on the theme of rokudan-, Susheela Raman- Nagumomo-, Vanessa Mae- Fantasy on a theme from caravans ), fotoğraf makinesi, kamera

Mekan: Çă̆daş Drama Derneği İstanbul Şubesi Dersliği

\section{Kazanımlar:}

- Kendisine ait beden imgesini fark eder.

- Beden farkındalığg düşüncesi üzerine fikirlerini söyler.

- Otantik (kendine has) devinimini keşfeder.

Atölye başlamadan katılımcılar verilen 3 soruyu cevaplandırır (Bakınız Ek-1).

\section{Süreç}

\section{Hazırlık / Isınma}

\section{Etkinlik: Fiziksel Isınma}

Bedenin tüm uzuvlarını çalışmaya ısındıracak egzersizler yapılır. Sırasıyla; baş, omuz, kollar, eller, bel, bacaklar, ayaklar üzerine çalışılır. Yoga ve tangoda kullanılan esneme ve denge temrinleri yapılır.

Ardından katılımcılar üç gruba ayrılır ve kendi içlerinde bir çember oluştururlar. Bedenlerini serbest bırakıp oldukları yerde minik sıçramalarla tüm uzuvlarını sinirleri boşalmış gibi kontrolsüz hareket ettirirler. Bir yandan da gün içinde ne yaptıklarını, bedenlerini nasıl hareket ettirdiklerini, gözlemledikleri kişileri düşünürler. Konuşabilirler; fakat bu süreçte daha çok kendileriyle konuşur haldedirler. Etkinlik sonrası, önceden verilen ödev üzerine katılımcılar o hafta yaşadıkları deneyimlerini paylaşırlar ve paylaşıma dair bir slogan yazarak mekânın istedikleri bir yerine yapıştırırlar.

Katılımc1ların yazdıkları yazılar:

- $\quad$ Eklemlerin kireçlendiğinde her şey için çok geç olacak. Çok geç olmadan bir şeyler yap

- Bedeninden bir haber nereye gidiyorsun?

- Taş gibi kalmış uyumuş

- Dar zamanlarda hızlı olmak, iş görecek kadar hareketlenmek 
- Korku kabuk bağlamış meraka, endişeli gözler sığınmış baba böğrüne

- Sokakta yürüyenler gergin, bir yere doğru gidiyor

- $\quad$ DOKUN, DEĞISsTIIR, BAĞIR herkes duysun. Çeperin son bulsun

- Kisır Döngü

\section{Etkinlik}

A. Katılımcılar ikili grup olur ve kendi içlerinde A ve B diye ayrılırlar. A'lar, B'lerin duruşunu ve yürüyüşünü gözlemler. Ardından önce B'nin nasıl yürüdüğünü ve durduğunu gösterirler. Sonra bu yürüyüşü ve duruşu karikatürize ederler. B'ler de A'ların duruşunu ve yürüyüşünü gösterip karikatürize eder.

Lider; "Bedenimizde başımızdan başlayan ve aşağıya inen bir sopa olduğunu düşünebiliriz. Bu sopa bedenimizi boylamasına ikiye ayırır. Omuriliğimizin başlangıçtaki şekli, bizim duruş alışkanlıklarımıza göre zamanla yeniden şekil alır. Masa başında çalışmanın bedene verdiği biçim ile ayakta çalışan bedenin biçimi farklılık gösterir." der. Katılımcıların duruşları üzerine çalışılır.

B.Kalıbını çıkar! (Bedensel imge) Katılımcılar dağıtılan Kraft kağıtlara kendi bedenlerinin imgesini çizerler. Ardından eş olur A-B diye ayrılırlar. Önce A'lar B'leri yeni bir kraft kâğıda yatırarak B'lerin kalıbını çıkarır. Sonra B'ler A'ların kalıbını çıkarır. Beden imgelerini, kendi çizdikleri ve kalıpları üzerinden karşılaştırırlar. (Bkz. Ek-8)

\section{B) Canlandırma}

\section{Etkinlik}

İkili grup olunur. Sandığı ben ve fiziksel ben arasındaki farklılıktan yola çıkarak katılımcılar şiir yazarlar. Herkesin şiirinin adı bedenimdeki yabancıdır. Şiiri yazan kişi kendiliğinden (spontan) devinirken, eşi şiirini okur ve eşler değișir. (Mari Boine Persen'in şarkısı devinimlere eşlik eder.)

Bedenimdeki Yabancı: “A. Boal’in verdiği bir örnek oldukça açıklayıcı olmaktadır: Her gün uyanıp işe ya da okula gidiyoruz. Oradaki 'rol'ün dayattığı bir beden kullanımı, devinim dili var. Bu dili kullanmak zorunda bırakıldığımız (A. Boal'cesi, ezildiğimiz) için yabancısıyızdır gövdemizin." (Katılımcı anketindeki katılımcının cümlesi direkt alınmıştır.)

\section{Ara Değerlendirme}

Çember olunur, yere oturulur. Katılımcılardan birine herhangi bir nesne (yüzük, eşarp, taş...v.b.gibi) verilir. Nesneyi eline alan katılımcı, etkinlikteki karşılaştırmaya dair aklına gelen ilk kelimeyi söyler. İki tur bu şekilde dönülür ve bu kavramlar da not kağıtlarına yazılarak sloganların bulunduğu yerlere yapıştırılır. Beden algısı üzerine konuşulur.

Yazılan kavram ve cümlelerden bazıları:

- Kendimizi sevmek için bedenimizi sevmek gerekir.

- Çok uzun zamandır birlikte olduğumuzu düşündüğüm bedenimi aslında yeni tanıyorum.

- Bedenimin aç olduğu yere geldim.

- Bedenime haksızlık ettiğimi düşündüm.

- Dayatılan fit vücut meselesi olmadan da oluyormuş. Olduğumuz gibi de oluyormuş.

- Bol şanslar demek için bedene onun sınırlarını zorlamak gerekir 
- Bedenimi kullanamamak beni mutsuz ediyor.

- Bedenini organlara bölme

- Bedenimizle yüzleşme

- $\quad$ Fark ettim

- İçindeyim

- Doyuyorum

- Dokun

- Hareket

- Sevmek

Lider, "Kişilerin algıladıkları bedenleri (beden imgesi) ile fiziksel olarak var olan bedenleri arasında farklar ortaya çıkabiliyor. Örneğin, ergenlerin özellikle kendilerini olduklarından daha kilolu gördükleri yapılan araştırmalar sonucunda tespit edilmiştir. Beden imgesi, bedene dair tüm anlamların, imajların, hayal gücünün ürünüdür.* Aradaki fark zihnin algısı ile ilgilidir. Örneğin, medya aracılığı ile insanlar kendilerini televizyondaki kadınlar ya da erkekler gibi hissediyorlar. Onlara benzemek için çaba sarf ediyorlar. Herkes televizyonda gördüğü kadın ya da adamla özdeşleşiyor. Kendini prens sanan erkek, bir prenses arıyor. Bedenler, yüzler, stereotip olarak karşımıza çıkıyor. Geçmiş zamanda kötü, günahkâr olarak görülen beden, bugün insanların övünç kaynağı hatta bazılarının var oluş nedeni haline gelmiş durumdadır." der.

(Tunç, A. (2007). "Ergenlerin olumsuz beden imgelerine yönelik geliştirilen bilişsel-davranışçı ve değiştirilmiş sanat terapisi programlarının etkinliklerinin karşılaştırılması” Yüksek Lisans Tezi: Ankara.)

\section{Etkinlik}

A. Katılımcılar mekânda istedikleri bir yerde konuşlanırlar. Müzik olmadan ve birbirleriyle ilgilenmeden en rahat oldukları pozisyonu bulmaya çalışırlar. Buldukları pozisyonda bir süre durur ve daha rahat bir pozisyon ararlar. Bu arayış bir süre devam eder ve devinime dönüşür. Bulunan pozisyonlardan üçü akılda tutulur.

$\mathrm{Bu}$ arayış sürecini Ida Shigemi kedinin gerinmesine benzetir. Kişi, estetik kaygı gözetmeksizin bedenini serbest bırakarak devinir. Kendine has devinimlerini fark eder. Herkesin otantik devinimi kendine has olacağ 1 için herkesinki birbirinden farklı olacaktır. (Ida Shigemi Atölyes’inden. Çatı Dans, 2011)

B. Katılımcılar eş olur ve karşı1ıklı otururlar ve birbirlerinin gözlerinin içine bakarak, bir ellerini yukarı bakacak şekilde bir ellerini de aşağıya bakacak şekilde tutarlar. Böylece avuç içleri birbirine bakar. Bir süre bu şekilde beklerler ve avuçları arasındaki akışı hissederler.

C. Bir süre sonra ayağa kalkarlar ve ayakta kıpırdamadan birbirlerinin gözlerinin içine bakmaya başlarlar. Eşlerden biri bilinçli olarak devinimi başlatmak için bir şey yapmaz; fakat bir süre sonra karşılıklı etkileşimle devinimin açığa çıktığı görülür. Katılımcıların birbirlerini yansımaları izlenir.

\section{Etkinlik}

Ardından eşler bir araya gelir ve daha önce duvara yapıştırılan sloganlardan ve kavramlardan birini seçerler. İki kavram ve iki slogan ve devinme noktaları olan 3 pozisyonlarını da bir araya getirerek otantik devinimlerinin dramatik eylemini ellerindeki materyaller üzerinden kendileri belirleyerek çalışırlar. Mekân olarak, park, inşaat halinde bir apartman katı, buzhane, arabaların geçtiği bir otoban, mezarlık verilir.

\section{C) Değerlendirme}

\section{Etkinlik}


Atölye öncesi verilen sorular değerlendirmede yeniden cevaplanır.

\section{Etkinlik}

Katılımcılar ilk eşlerine giderler. Sırasıyla birbirlerine masaj yaparak bedenlerin gevşemesini sağlarlar. Nasıl masaj yapılacağını lider gösterir. Katılımcılar da lideri takip ederek masaj yaparlar.

\section{Oturum başında ve sonunda verilen değerlendirme soruları}

Zihninizde var olan bedensel biçiminizi (bedensel imgenizin) düşündünüz mü?

\begin{tabular}{|ccc|}
\hline Her zaman & Bazen & Hiç \\
\hline Bedeniniz ve onun hareketlerini fark ettiniz mi? & Hiç \\
\hline Her zaman & Bazen \\
\hline Kendinize has (otantik) devinimlerinizi fark ettiniz mi? & Hiç \\
\hline Her zaman & Bazen & \\
\hline
\end{tabular}

\section{Beşinci Oturum}

Tarih: 21.04 .2012

Konu: Dans eden adımlar ve ritim

Grup: Çağdaş Drama Derneği İstanbul Şubesi Katılımcılarından oluşan (Eğitmenlik ve liderlik programında en az 3. aşamayı bitiren katılımcılardan oluşan grup) 12 kişi

Süre: $90^{\prime}+90^{\prime}$

Yöntem: Yaratıcı Drama

Teknik: Doğaçlama, rol oynama, rüya tekniği

Araç ve Gereç: Kâğıt, kalem, boya, CD Player, fotoğraf makinesi, kamera, ayak stickerları, Müzik (Isınma için şarkılar: Secret Garden -Lotus-,Karşı pencere film müziği, Ayub Ogada -Kothbiro-, Fazıl SayKara toprak-, Eleni Karaindrou-Ağlayan Çayır ve eternity and a day film müzikleri-, Fountain film müziği, Manu Chao- Clandestino-, Marie Boine Persen-Vuoi vuoi mu-,trio jubran-masar-, V for Vendetta film müziği, Ravi Shankar- Improvisation on the theme of rokudan-, Susheela Raman- Nagumomo-, Vanessa Mae- Fantasy on a theme from caravans; adımlar üzerinde; tren sesi, -Something stupid- Nicole Kidman Robbie Williams), kumaşlar, tüller, zincir ve şeritler.

Mekan: Çağdaş Drama Derneği İstanbul Şubesi Dersliği

\section{Kazanımlar:}

- Beden koordinasyonu sağlar.

- Bedeninin ezberinin bozulmasını sağlar.

- Pasif kas grupları hareket eder.

- Mekânda bulunduğu yerde hareket eder. 
- Ritimle birlikte hareket eder.

\section{Süreç}

\section{A) Hazırlık / Isınma}

\section{Etkinlik: Fiziksel Isınma}

Bedenin tüm uzuvlarını çalışmaya ısındıracak egzersizler çemberde yapılır. Sırasıyla; baş, omuz, kollar, eller, bel, bacaklar, ayaklar üzerine çalışılır.

\section{Etkinlik}

\section{A. Yürüyüşler}

Katılımcılar ağır çekimde (slow motion) yürürler.

Katılımcılar yan yana durur ve birbirlerine yakın olan bacaklarını birbirine dolayıp yürümeye çalışırlar (Çapraz bacaklar).

Diğer versiyonunda ayaklarını dolamadan, içteki ayaklarını tek ayak gibi yan yana tutarak yürümeye çalışırlar. Böylece iki kişi yan yana geldiğinde, yalnızca üç ayakları varmış gibi yürürler. (Bir önceki egzersizden esinlenerek geliştirilmiştir.)

B. Beden koordinasyonu: $\mathrm{Bu}$ temrinde katılımcının bedeninin ezberini bozması hedeflenir; fakat temrinleri başarıyla gerçekleştirmeleri gibi bir ölçüt yoktur.

- Sağ el geriye giderken, sol el öne gider.

- Sağ el daire çizerken, sol el artı işareti yapar.

- Sol ayak daire çizerken sağ el isim yazar.

C. Kolombiya Hipnozu: Tüm bedeninin hareket etmesinin amaçlandığı çalışmada katılımcılar birbirini takip eder.

1. İkili grup olunur. Eşlerden biri el ayasını parmakları yukarı bakacak şekilde diğerinin yüzüne yakın mesafede tutar. Diğeri de tıpkı hipnoz olmuşçasına bu eli takip eder. Yöneten kişi, takip edeni zorlar ki; bedeninin çalışmayan diğer kasları da çalışsın. Liderin yönergesi ile eşler değişir.

2. Çember olunur. Ortaya bir gönüllü geçer ve yerinde sabit kalmak koşuluyla devinmeye başlar. Diğer gönüllü ortadaki kişinin herhangi bir yerine odaklanır ve onu takip ederek devinir. Üçüncü bir kişide seçtiği iki kişiden birinin bir yerine odaklanır ve devinir. Tüm grup birbirini takip edene kadar etkinlik devam eder. Bir süre birlikte hareket ederler. Liderin yönergesiyle bir kuş sürüsüne dönüşürler. Birlikte uçarlar. Uçarken bir noktayı takip etmeyi bırakıp birbirlerini takip ederek "V" halini alırlar ve liderin her el çırpışında "V" nin ucundaki kişi sona geçer ve yerine arkasındaki kişi gelir. Deneyerek en uyumlu şekilde akışı gerçekleştirirler. (Denedikten bir süre sonra birbirlerini omuzlarından takip etmişler ve sırasıyla bir sağdan bir soldan olmak üzere "V" nin ucuna geçmişlerdir.). Bir süre sonra liderin yönergesiyle balık sürüsü olurlar ve önce sağa, sonra sola, sonra geriye dönerler. Lider yönerge vermeyi bırakır. Grup ritmini yakalayıp aynı anda belirlenen yönlere dönmeye çalışır. -Ek olarak, otobanda aynı yönde gitmeye çalışan arabalar olup, sinyal vererek birbirlerini sollayabilirler. (Yürüyüşler, beden koordinasyonu, Kolombiya hipnozu, Augusto Boal'in oyuncu ve oyuncu olmayanlar için oyunlar adlı kitabından alınmıştır.)

\section{Etkinlik}

Mekâna, hazırlanan ayak stickerları yapıştırılır. Katılımcılar iki gruba ayrılır. İlk grup bu stickerlar 
üzerine basarak bedenlerini serbest bırakıp liderin yönergesiyle hızlarını değiştirerek yürür. Adımlara konsantre olurlar. İkinci grup onları seyreder. Ardından ikinci grup adımları takip ederek yürür. Katılımcılar istedikleri yerde ayakları yerdeki adımların üzerinde olacak şekilde konuşlanırlar. Lider katılımcılara trende olduklarını söyler. Tüm grup giden trene aynı ritmi vererek sallanır. Bulundukları yerden yavaş yavaş uzaklaşmaya, otobüsün içinde yer değiştirmeye başlarlar. Liderin yönergesiyle tren bazen fren yapar, yavaşlar; bazen hızlanır. Tren sesi kullanılır.

\section{B) Canlandirma}

\section{Etkinlik}

Lider mekânı değiştirir ve bir partide olduklarını söyler. Bu partide kimi çiftler iletişim kurmakta, kimi dans etmekte, kimi yakınlaşmaya, kimi uzaklaşmaya çalışmakta kimi sadece bir yer değiştirme halinde olabilir. Tüm bunlar slow motion olarak gerçekleştirilir. Yerdeki adımlar üzerinde hareket edilir. (Grup birlikte eş zamanlı olarak kendiliğinden (spontan) oluşan bir akışın içinde doğaçlama yapar.)

\section{Ara Değerlendirme}

Sözel olarak katılımcılar adımlara uygun çalışma ve hep birlikte hareket etme üzerine yaşadıkları deneyimi paylaşırlar. (Katılımcılardan kimi çocukların gösteride yerlerini belirlemek için, kimi çocuklara gösterideki adımları öğretmek için bu etkinliği uyarlayabileceklerini dile getirdi.)

\section{Etkinlik}

- Rio’da karnaval: Lider üç kişilik gruplar oluşturur. Her grup kendi içinde 1,2,3 diye numaralandırılır. Lider, bir numara söyler (örneğin 1) ve bütün 1 numaralar istedikleri bir ritmik sesle ve hareketle dolaşmaya başlar. Diğer numaralar kendi gruplarındaki 1 numaralı kişiyi takip eder ve taklit ederler. Sırasıyla 2 ve 3 de takip edildiğinde, katılımcılar yönerge ile birlikte kendi istedikleri sesi çıkarır ve hareket ederler. Lider birleşin dediği zaman gruplar birleşir ve her üçlüden bir kişi bir diğerini takip etmeye başladığında üçüncü kişide diğer iki kişiye uyar.

- (Augusto Boal'in Oyuncular ve oyuncu olmayanlar için oyunlar kitabındaki oyundan alınmıştır.)

- Ma me mi mo: Grup mekânda serbest dolaşır. Lider elindeki sopaları birbirine vurarak bir ritim verir. Katılımcılar her vuruşa karşılık gelecek bir hareket yapar. Dördüncü vuruş tamamlandığında katılımcılar durur ve lidere bakarak ma me mi mo derler. Bu söyleyiş belli bir ritim ve tempoyla ilerler. Lider zaman zaman hızlanır, yavaşlar. Katılımcılar da bu hıza uyar. Ardından lider dörderli gruplar oluşturur. Bir grup camın önünde bir grup sağda bir grup solda konuşlanır ve kendi gruplarından ayrılmadan ve bulundukları noktadan çok uzaklaşmadan etkinliği gerçekleştirirler.

\section{Etkinlik}

Katılımcılar iki gruba ayrılır. Geleceğe dair duyulan ortak bir kaygı bulunur ve bu kaygının rüyası canlandırılır. Grupta bazı kişiler ritim tutar ya da ritim tutarak devinir. Diğerleri de ritme uyarak dans eder (Ritimle söylenen bir cümle ya da bir şarkı ya da yalnızca ritmik bir ses olabilir.).

\section{C) Değerlendirme}

\section{Etkinlik}

Katılımcılar kâğıda atölye sürecinde içlerinde oluşan ritmin akışını çizerler. Kâğıttaki ritmi kişi bedenine vurarak gösterir ve tüm grup verilen ritmi aynı anda tekrarlar. 